Linköping Studies in Science and Technology

Dissertation No. 1564

\title{
YTTRIA-STABILIZED ZIRCONIA AND GADOLINIA- DOPED CERIA THIN FILMS FOR FUEL CELL APPLICATIONS
}

\section{Steffen Sønderby}

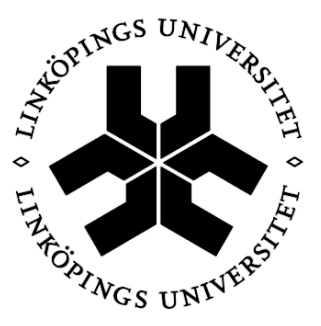

\section{Linköping University}

\section{INSTITUTE OF TECHNOLOGY}

Thin Film Physics Division

Department of Physics, Chemistry and Biology (IFM)

Linköping University

SE-581 83 Linköping, Sweden 
(C) Steffen Sønderby, unless otherwise stated ISBN: 978-91-7519-441-7 ISSN: 0345-7524

Printed by LiU-Tryck, Linköping, Sweden, 2014 
Solid oxide fuel cells convert chemical energy directly into electrical energy with high efficiency and low emission of pollutants. However, before fuel cell technology can gain a significant share of the electrical power market, the operation temperature needs to be reduced in order to decrease costs and improve the durability of the cells. Application of thin film electrolytes and barrier coatings is a way of achieving this goal.

In this thesis, I have investigated film growth and microstructure of yttriastabilized zirconia (YSZ) and gadolinia-doped ceria (CGO) thin films deposited by physical vapor deposition. The aim is to make industrially applicable coatings suitable for application in solid oxide fuel cells (SOFCs). For this purpose, the coatings need to be thin and dense. YSZ coatings were prepared by pulsed direct current (DC) magnetron sputtering and high power impulse magnetron sputtering (HiPIMS) in both laboratoryand industrial-scale setups.

Industrial-scale pulsed DC magnetron sputtering of YSZ showed that homogenous coating over large areas was possible. In order to increase film density of the YSZ, HiPIMS was used. By tuning deposition pressure, peak power density and substrate bias voltage it was possible to deposit noncolumnar thin films without voids and cracks as desired for SOFC applications.

CGO coatings were deposited by pulsed DC magnetron sputtering with the purpose of implementing diffusion barriers to prevent reactions between $\mathrm{Sr}$ from the SOFC cathode and the electrolyte. A model system simulating a SOFC was prepared by depositing thin CGO and YSZ layers on cathode material. This setup allowed the study of $\mathrm{Sr}$ diffusion by observing $\mathrm{SrZrO}_{3}$ formation using X-ray diffraction while annealing. Electron microscopy was subsequently performed to confirm the results. The study revealed $\mathrm{Sr}$ to diffuse along column/grain boundaries in the CGO films but by modifying the film thickness and microstructure the breaking temperature of the barrier could be increased.

CGO thin films were implemented in metal-based SOFC and the influence of film microstructure and thickness on the electrochemical performance of the cell was studied. Cell tests showed that an area specific resistance (ASR) down to $0.27 \Omega \mathrm{cm}^{2}$ could be obtained at $650{ }^{\circ} \mathrm{C}$ with sputtered CGO barrier layers in combination with a lanthanum strontium cobaltite cathode. In comparison a spin-coated CGO barrier resulted in an ASR value of $0.50 \Omega \mathrm{cm}^{2}$. This shows the high effectiveness of the sputtered barrier in obtaining state-of-the-art performance.

In summary, this work provides fundamental understanding of the deposition and growth of YSZ and CGO thins films and proves the prospective of employing thin film barrier coatings in order to obtain high-performing SOFCs. 


\section{POPULÄRVETENSKAPLIG SAMMANFATTNING}

Genom historien har människan alltid strävat efter att förbättra sina levnadsvillkor genom att förbättra eller utveckla nya verktyg och material. Utvecklingen av nya material har i hög grad påverkat civilisationen uppkomst, vilket framgår av det sätt som vi nu namnger perioderna i mänsklighetens historia efter de material som använts, till exempel sten-, brons- och järnålder. Idag lever vi i ett högt utvecklat samhälle med många fördelar som bygger på de framsteg som gjorts genom historien. Vi har fortfarande många utmaningar att lösa inom en snar framtid för att kunna upprätthålla vår levnadsstandard. Därför är det alltid viktigt att forska och utveckla nya material. Ett av de problem vi har i dag är den höga konsumtionen av fossila bränslen, som dels ger stora mängder koldioxidutsläpp som bidrar till den globala uppvärmningen och dels kommer att ta slut någon gång. För att åtgärda detta problem är det nödvändigt att utveckla teknik för att förbättra energiförsörjningen.

Bränsleceller är ett effektivt och miljövänligt sätt att producera el. En bränslecell producerar el och värme, när de matas med syrgas och bränsle (exempelvis vätgas, biobränslen, eller för delen fossila bränslen). Själva namnet bränslecell är ganska missvisande, eftersom det inte sker någon konventionell förbränning i cellen. Istället är det en direkt omvandling av energin i de molekyler som ger elektricitet. Denna omvandling kan göras mycket effektivt och därmed kan vi utnyttja bränslet bättre än vid förbränning. Det finns flera olika typer av bränsleceller, men gemensamt för dem alla är att de består av tre delar: en katod, en anod och en elektrolyt. Bränslet tillförs vid anoden medan syre tillsätts katoden. Elektrolytens uppgift är att separera katoden från anoden, samtidigt som det kan drivas en ström mellan dem.

Jag har utvecklat elektrolytmaterial för den typ av bränslecell som kallas fastoxidbränsleceller. Namnet kommer av det faktum att elektrolyten är ett oxidmaterial. Denna typ av bränslecell skiljer sig från andra genom att flödet genom elektrolyten består av syrejoner. Samtidigt som syre går genom elektrolyten från katoden till anoden, går ett flöde av elektroner i den motsatta riktningen genom en extern krets. Det är denna ström som kan användas för att driva elektriska apparater.

Fastoxidbränsleceller är en av de mest effektiva typerna av bränsleceller, men tyvärr kräver de mycket höga temperaturer $\left(800-1000{ }^{\circ} \mathrm{C}\right)$, vilket gör det mycket dyrt eftersom material som tål så höga temperaturer är dyra. Min forskning har fokuserat på att utveckla material som kan sänka driftstemperaturen, vilket gör det möjligt att producera billiga bränsleceller eftersom tekniken då blir lönsam. I denna avhandling har jag studerat möjligheten till industriell produktion av tunna filmer av två material. Det första materialet, som kallas yttria-stabiliserad zirkoniumoxid (YSZ i kortform), är en oxid bildad av syre och metallerna zirkonium och yttrium. YSZ är det vanligaste elektrolytmaterial i fastoxidbränsleceller. Genom att göra elektrolyten är mycket tunn kan 
driftstemperaturen för bränslecellen sänkas och tekniken göras lönsam. Det andra materialet jag har studerat är cerium-gadoliniumoxid (förkortat CGO), vilket som namnet antyder är en oxid av de sällsynta jordartsmetallerna cerium och gadolinium. CGO används som en barriär mellan YSZ-elektrolyten och nyutvecklade och effektiva katodmaterial. Sådana katoder innehåller den mycket reaktiva metallen strontium $(\mathrm{Sr})$, som utan barriär skulle diffundera och reagera med YSZ-elektrolyten och bilda strontiumzirkonat som kommer att förhindra en jonström genom elektrolyten.

De tunna lager av YSZ och CGO jag har jobbat med är några mikrometer tunna (dvs. några tusendels millimeter) och kallas tunna filmer. De produceras av en metod som kallas "sputtring". Sputtring betyder att material förångas med ett jonbombardemang på en källa och låta atomerna sätta sig på en yta, där en tunn film bildas. Processen sker i en vakuumkammare, där trycket är en miljarddel av atmosfärstrycket. I denna vakuumkammare bildas ett plasma, alltså en gas som huvudsakligen är joniserad. Genom att spänningssätta materialet som ska förångas, kan man få jonerna att bombardera materialet. Detta gör att atomerna lossnar och sedan kan kondenseras där du vill belägga en tunn film. Eftersom denna process sker på atomnivå, finns det flera knep för att påverka strukturen på den tunna filmen på så sätt få de egenskaper som du önskar.

Det finns flera olika sputtringstekniker. Jag har använt två olika metoder, nämligen den mycket utbredd teknik som kallas "magnetronsputtring" och en relativt ny teknik som kallas "HIPIMS". Fördelen med HIPIMS är att man kan få mycket fler joner som bildas i plasmat, vilket betyder att beläggningsflödet kan styras. Dessa joner överför också mycket mer energi till den tunna filmen, vilket ger större möjligheter att påverka filmtillväxten.

I mitt arbete har jag använt både industriell beläggningsutrustning och små laboratorieutrustningar. Mitt arbete har två huvudsakliga delar: studier av YSZ tunnfilmselektrolyter och studier av CGO-barriärlager. I studierna av YSZ har jag undersökt möjligheten att $\mathrm{i}$ industriell skala producera enhetliga YSZ tunna filmer över stora områden, vilket är nödvändigt för att kommersialisera processen. Dessutom har jag både i laboratorieskala och i industriell skala undersökt potentialen i HIPIMS teknik för att producera YSZ filmer av bättre kvalitet. I studierna av CGO har jag undersökt de mekanismer som är i spel när strontium diffunderar genom CGO. Detta är intressant eftersom om du vet hur diffusion sker så kan du bättre förhindra det. Dessutom har jag gjort CGO spärrskikt, tillämpat dem i verkliga bränsleceller och visat deras förmåga att förhindra strontiumdiffusion, något som förbättrar bränslecellerna elektricitetsproduktion. 


\section{POPULÆRVIDENSKABELIG SAMMENFATNING}

Op gennem historien har mennesket altid stræbt efter at forbedre sine levevilkår ved at forfine eller udvikle nye redskaber. Udviklingen af nye materialer har haft stor indflydelse på civilisationers opståen, hvilket tydeligt fremgår af den måde, vi i dag navngiver perioder i menneskets historie efter de materialer, som anvendtes, såsom sten-, bronze- og jernalder. I dag lever vi i et højtudviklet samfund med en masse goder, som bygger på de landvindinger, der er gjort gennem historien. Vi har dog stadig en række udfordringer, som må adresseres i nær fremtid for at opretholde en ønsket levestandard. Derfor er det til stadighed vigtigt at forske i udviklingen af nye materialer. Et af de problemer, vi har i dag, er det store forbrug af fossile brændstoffer, som dels udleder store mængder $\mathrm{CO}_{2}$, der dels bidrager til drivhuseffekten og dels slipper op på et tidspunkt. For at afhjælpe dette problem er det nødvendigt at udvikle teknologier til en bedre energiforsyning.

Brændselsceller er en effektiv og miljøvenlig måde at fremstille elektricitet på. En brændselscelle producerer elektricitet og varme, når den tilsættes ilt $\left(\mathrm{O}_{2}\right)$ og et brændstof (f.eks. brint). Selve navnet brændselscelle er ret misvisende, idet der ikke sker en traditionel forbrænding i cellen, men derimod en direkte omdannelse af energien bundet $i$ molekylerne til elektricitet. Denne omdannelse kan ske meget effektivt, og man kan derfor udnytte sit brændstof bedre. Der findes flere forskellige typer brændselsceller, men fælles for dem alle er, at de består af tre lag: en katode, en anode og en elektrolyt. Brændstoffet tilsættes ved anoden, mens ilt tilsættes katoden. Elektrolyttens opgave er at adskille katoden fra anoden, men samtidig sikre at der kan løbe en strøm mellem disse. Jeg har forsket $i$ at udvikle elektrolytmaterialer til den type brændselscelle, som kaldes fastoxidbrændselscellen. Navnet kommer af, at elektrolytten er et oxidmateriale. Denne type brændselscelle adskiller sig fra andre ved, at strømmen gennem elektrolytten ikke består af ilt-ioner $\left(\mathrm{O}^{2-}\right)$. Samtidig med at der løber $\mathrm{O}^{2-}$ gennem elektrolytten fra katoden til anoden, sendes en strøm af elektroner den anden vej via et eksternt kredsløb. Det er denne strøm man kan bruge til at drive sine elektriske apparater.

Fastoxidbrændselscellen er en af de mest effektive brændselscelletyper, men kræver desværre meget høje temperatur $\left(800-1000{ }^{\circ} \mathrm{C}\right)$, hvilket har gjort den meget dyr, da materialer, som kan klare så høje temperaturer, er dyre. Min forskning har drejet sig om at udvikle materialer, som kan sænke driftstemperaturen, og derved gøre det muligt at producere billige brændselsceller, så teknologien bliver rentabel.

I denne afhandling har jeg undersøgt muligheden for industriel fremstilling af tynde film af to materialer. Det første materiale, kaldet ytrria stabiliseret zirkonia (i daglig tale YSZ), er en oxid dannet ud af ilt og metallerne zirkonium og yttrium. YSZ er det mest anvendte elektrolytmateriale i fastoxidbrændselsceller. Ved at lave elektrolytten meget tynd kan brændselscellens driftstemperatur sænkes, og teknologien gøres rentabel. 
Det andet materiale, jeg har undersøgt, er cerium gadolinium oxid (forkortes CGO), der som navnet siger, er et materiale bestående af ilt og de sjældne jordarter cerium og gadolinium. CGO skal bruges som en barriere mellem YSZ-elektrolytten og nyudviklede og mere effektive katodematerialer. Det er nødvendigt, da disse katoder indeholder meget reaktivt strontium $(\mathrm{Sr})$, der ellers vil diffundere og reagere med YSZ-elektrolytten og danne strontiumzirkonat, som vil forhindre en ion-strøm gennem elektrolytten.

De tynde lag af YSZ og CGO som jeg har arbejdet med, er ganske få mikrometer tynde (dvs. få tusindedele af en millimeter) og kaldes tyndfilm. De er fremstillet ved en metode, som kaldes "sputtering". Sputtering går i alt enkelthed ud på, at man forstøver materiale til atomer fra en kilde og lader atomerne lægge sig på en overflade, hvorved en tyndfilm dannes. Processen foregår i et vakuumkammer, hvor trykket er en milliardtedel af atmosfæretrykket. I dette vakuumkammer danner man et plasma, hvilket er en gas, hvor en relativ stor del af partiklerne er elektrisk ladede. Ved at påtrykke en elektrisk spænding på det materiale, som man gerne vil forstøve, kan man få ionerne til at bombardere materialet. Herved vil atomer blive slået løs, og de kan derefter kondenseres der, hvor man gerne vil deponere en tyndfilm. Da denne proces foregår på atomart niveau, kan man lave flere tricks for at påvirke opbygningen af tyndfilmen og dermed opnå de egenskaber, som man søger.

Der findes flere forskellige sputtering-teknikker. Jeg har anvendt to forskellige teknikker, nemlig den meget udbredte teknik kaldet "magnetron sputtering" og en relativ ny teknik kaldet "HiPIMS". Fordelen ved HiPIMS er, at man kan få dannet langt flere ioner i plasmaet samt får ioniseret en del af de atomer, som bliver slået løs fra belægningskilden. Disse ioner overfører betydeligt mere energi til tyndfilmen, og giver derved større muligheder for at påvirke filmvæksten.

I mit arbejde har jeg både anvendt industrielt belægningsudstyr og mindre laboratorieudstyr. Mit arbejde kan deles op i to dele: nemlig studiet af YSZtyndfilmselektrolytter og studiet af CGO tyndfilmsbarrierelag. I studiet af YSZ har jeg undersøgt muligheden for på industriel skala at producere ensartede YSZ tyndfilm over store arealer, hvilket er nødvendigt for en kommercialisering af processen. Derudover har jeg både på laboratorieniveau og industriel skala undersøgt potentialet i HiPIMSteknikken til at fremstille YSZ-film af bedre kvalitet. I studiet af CGO har jeg undersøgt hvilke mekanismer, der er i spil, når strontium diffunderer gennem CGO. Dette er interessant, for hvis man ved, hvordan diffusionen foregår, kan man bedre forhindre det. Desuden har jeg fremstillet CGO barrierelag, anvendt dem i ægte brændselsceller og derved demonstreret deres evne til at forhindre strontium diffusion, hvilket har forbedret brændselscellens elektricitetsproduktion. 


\section{PREFACE}

This Thesis is the result of my industrial PhD studies from 2010 to 2014 in the Thin Film Physics Division at Linköping University and the Tribology Centre at the Danish Technological Institute. The results of this work are presented in the appended papers, which are preceded by an introductory part intended to provide the reader a background to the field and the techniques that have been used in the research, as well as summarizing my contribution to the field. This thesis is based on my Licentiate thesis "Physical Vapor Deposition of Yttria-Stabilized Zirconia and Gadolinia-Doped Ceria Thin Films for Fuel Cell Applications" (No. 1552, Linköping Studies in Science and Technology), published 2012.

The aim of my research is to develop thin film electrolytes and diffusion barrier coatings for solid oxide fuel cells. By implementing thin films in fuel cells the electrochemical performance of the cell can be improved or the operation temperature decreased which will bring this technology closer to practical application.

The research is directly financially supported by Topsøe Fuel Cell, Kgs. Lyngby, Denmark and Nordforsk under the Private Public Partnership (PPP) PhD program (contract no. 9046). The purposes of the PPP PhD Program are to increase knowledge exchange between the Nordic countries and promote collaboration between industry and academia. Funding from this scheme requires the $\mathrm{PhD}$ student to be employed at a company in one Nordic country while studying in another Nordic country. In my case, this means being employed at the Danish Technological Institute, Aarhus, Denmark, while studying at Linköping University, Sweden where I have spent $2 / 3$ and $1 / 3$ of my time, respectively.

Additional financial support has been given by Nordic Innovation Centre (contract no. 09046), and the Swedish Foundation for Strategic Research (Ingvar Carlsson Award 3 to my supervisor Per Eklund). 


\section{INCLUDED PAPERS}

Yttria-stabilized zirconia thin films

\section{Paper I}

Reactive magnetron sputtering of uniform yttria-stabilized zirconia coatings in an industrial setup

S. Sønderby, A. J. Nielsen, B. H. Christensen, K. P. Almtoft, J. Lu, J. Jensen,

L. P. Nielsen, and P. Eklund

Surface \& Coatings Technology, 206 (2012) 4126.

\section{Paper II}

Deposition of yttria-stabilized zirconia thin films by high power impulse magnetron sputtering and pulsed magnetron sputtering

S. Sønderby, A. Aijaz, U. Helmersson, K. Sarakinos, and P. Eklund Accepted for publication in Surface \& Coatings Technology.

\section{Paper III}

Industrial-scale high power impulse magnetron sputtering of yttria-stabilized zirconia on porous $\mathrm{NiO} / \mathrm{YSZ}$ fuel cell anodes

S. Sønderby, B. H. Christensen, K. P. Almtoft, L. P. Nielsen, and P. Eklund

In manuscript. 


\section{Paper IV}

Strontium diffusion in magnetron sputtered gadolinia-doped ceria thin film barrier coatings for solid oxide fuel cells

S. Sønderby, P. Lunca Popa, J. Lu, B. H. Christensen, K. P. Almtoft, L. P. Nielsen, and P. Eklund

Advanced Energy Materials, 3 (2013) 923.

\section{Paper V}

Magnetron sputtered gadolina-doped ceria diffusion barriers for metal-supported solid oxide fuel cells

S. Sønderby, T. Klemensø, B. H. Christensen, K. P. Almtoft, J. Lu, L. P. Nielsen, and P. Eklund

Manuscript submitted for publication.

\section{Paper VI}

High performance metal-supported solid oxide fuel cells with Gd-doped ceria barrier layers

T. Klemensø, J. Nielsen, P. Blennow, Å. H. Persson, T. Stegk, B. H. Christensen, and S. Sønderby

Journal of Power Sources, 196 (2011) 9459. 
My contribution to the included papers:

\section{Paper I:}

I was involved in the planning and the depositions, performed a large part of the characterization and analysis, and wrote the paper.

\section{Paper II:}

I was responsible for the planning, performed the sputter depositions, characterization and analysis, and I wrote the paper.

\section{Paper III:}

I was responsible for the planning and analysis, performed all synthesis and characterization, and I wrote the paper.

\section{Paper IV:}

I was responsible for the planning and analysis. I performed all synthesis and most characterization, and I wrote the paper.

\section{Paper V:}

I was responsible for the planning, performed all synthesis and most characterization, and wrote the paper.

\section{Paper VI:}

I was involved in the planning, performed all sputter depositions and part of the characterization. 


\section{PUBLICATIONS NOT INCLUDED IN THE THESIS}

Related papers

Paper VII

Development of Long-Term Stable and High-Performing Metal-Supported SOFCs

T. Klemensø. J. Nielsen, P. Blennow, A. Persson, T. Stegk, P. Hjalmarsson,

B. Christensen, S. Sønderby, J. Hjelm, and S. Ramousse

ECS Transactions, 35 (2011) 369.

Paper VIII

Highly oriented $\delta-\mathrm{Bi}_{2} \mathrm{O}_{3}$ thin films stable at room temperature synthesized by reactive magnetron sputtering

P. Lunca Popa, S. Sønderby, S. Kerdsongpanya, J. Lu, N. Bonanos, and P. Eklund Journal of Applied Physics, 113 (2013) 046101.

\section{Paper IX}

Optimization of the mechanical properties of magnetron sputtered diamond-like carbon coatings

S. Sønderby, A. N. Berthelsen, K. P. Almtoft, B. H. Christensen, L. P. Nielsen, and J. Bøttiger

Diamond and Related Materials, 20 (2011) 682. 


\section{ACKNOWLEDGMENTS}

I am grateful to a large number of people who have contributed, helped, and supported me during the course of my work. In particular I would like to thank:

* Per Eklund, my main supervisor. For giving me the opportunity to work in this exciting field and for being a great mentor.

- Lars Pleth Nielsen, Centre Manager at the Tribology Centre. For giving me the opportunity to perform industrial research at such a fascinating place as the Tribology Centre is.

- Colleagues at the Tribology Center at the Danish Technological Institute in Aarhus. You have always made it fun to go to work.

* Colleagues at IFM, in particular those in the Thin Film Physics, Plasma \& Coatings Physics, and Nanostructured Materials groups.

* Co-authors of the papers. It has been highly instructive and inspiring to discuss results with you and benefit from your experience

Collaborators at the Materials Science Group at Aarhus University.

Collaborators at Risø.

Collaborators at Topsøe Fuel Cell.

My family and friends. 


\section{TABLE OF CONTENT}

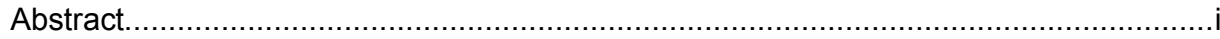

Populärvetenskaplig sammanfattning ................................................................. ii

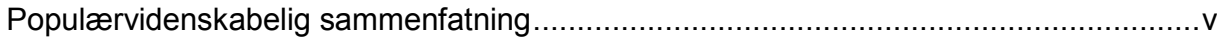

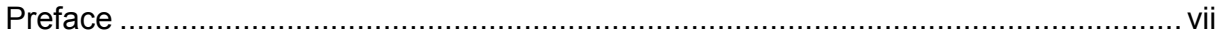

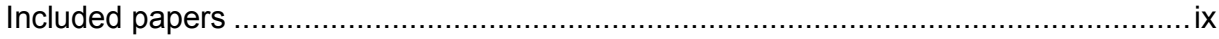

Publications not included in the thesis.................................................................... xiii

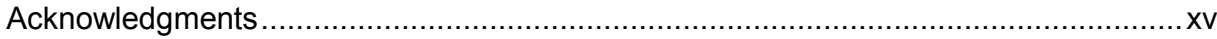

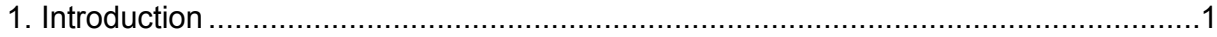

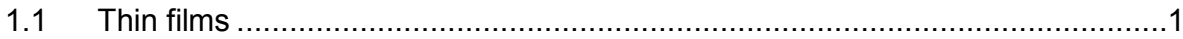

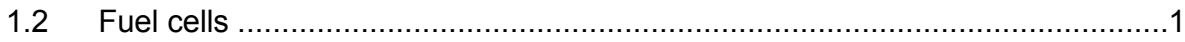

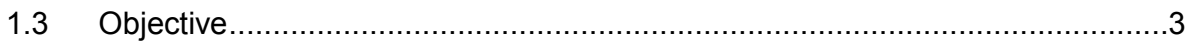

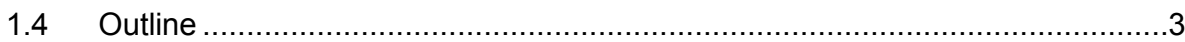

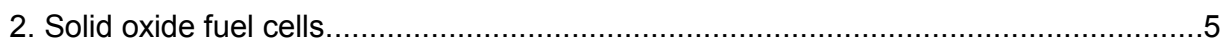

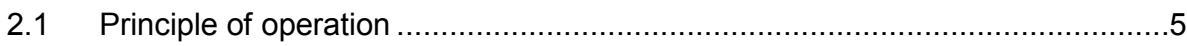

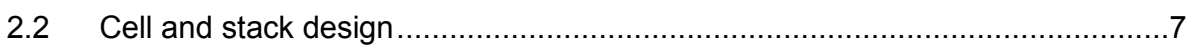

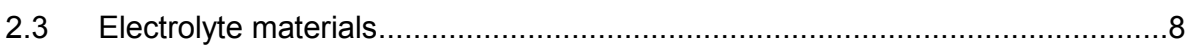

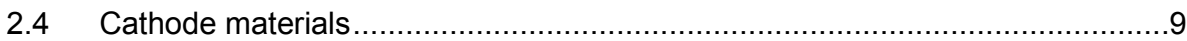

2.5 Anode materials .............................................................................. 10

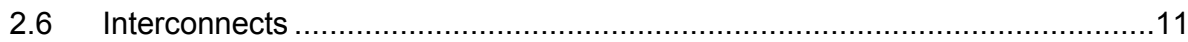

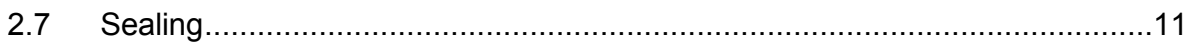

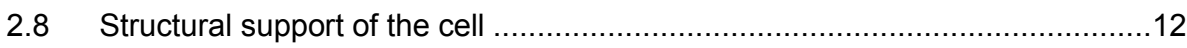

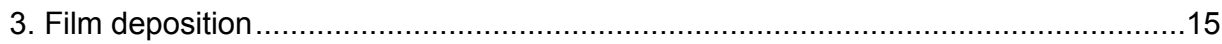

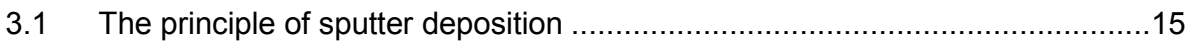

3.2 DC glow discharge ............................................................................ 16

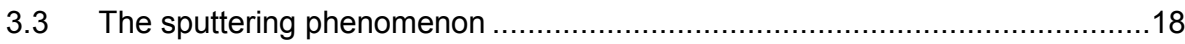

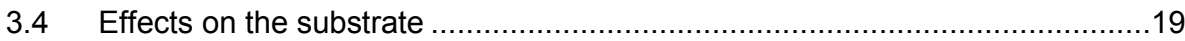

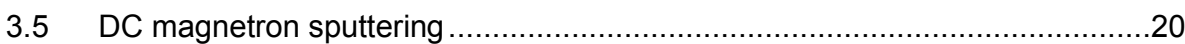

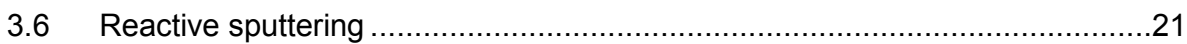

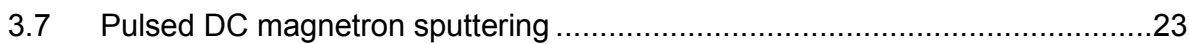

3.8 High power impulse magnetron sputtering (HiPIMS) .................................23

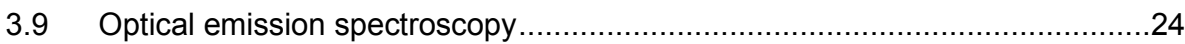

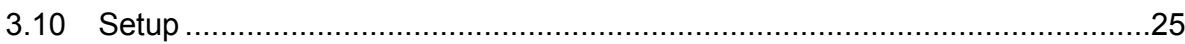

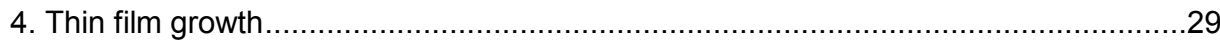




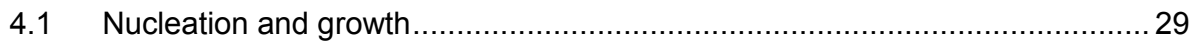

4.2 Controlling the growth of polycrystalline thin films.................................... 30

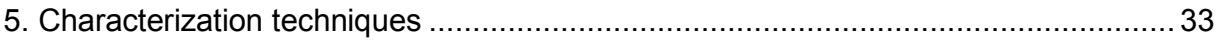

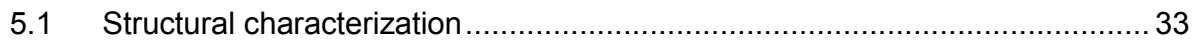

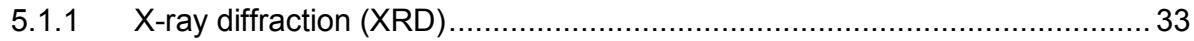

5.1.2 Scanning electron microscopy (SEM) …............................................... 37

5.1.3 Transmission electron microscopy (TEM) ….............................................. 38

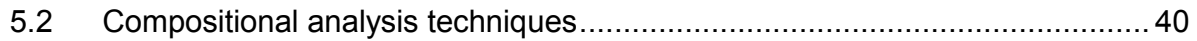

5.2.1 Energy dispersive X-ray spectroscopy (EDX or EDS) ….......................... 40

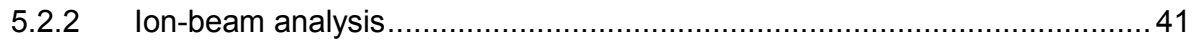

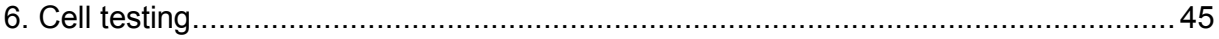

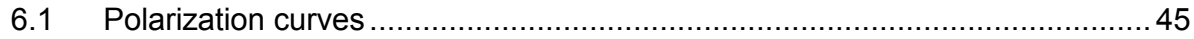

6.2 Electrochemical impedance spectroscopy (EIS) .................................... 46

7. Summary of the appended papers and contribution to the field .............................. 49

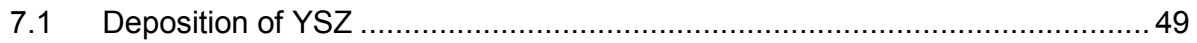

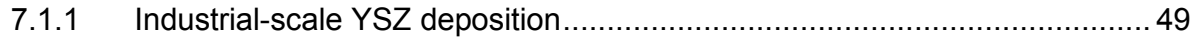

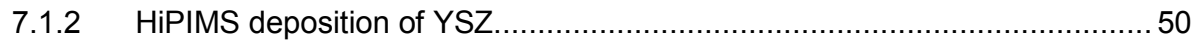

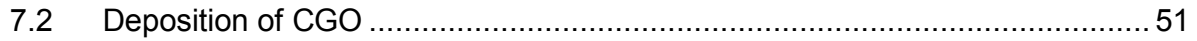

7.2.1 Strontium diffusion through sputtered CGO barriers............................... 51

7.2.2 Implementation of sputtered CGO barriers in metal supported SOFCs ....... 52

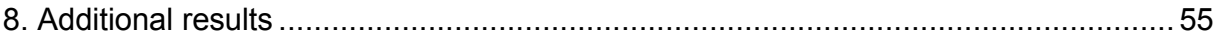

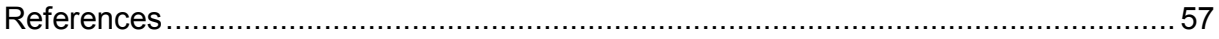

Papers I - VI 


\section{INTRODUCTION}

\subsection{Thin films}

Since the 1950s, the coating industry has expanded considerably and today thin films are found in numerous applications. By applying a coating with thickness ranging from a few nanometers to several micrometers, a surface with properties significantly different from those of the bulk material can be obtained. This allows the bulk material to be chosen based on requirements for mechanical support, stability, and cost. By surface treatment, the appropriate thin film can be applied to achieve unique or improved properties. Today, thin films are found in almost every manufacturing and technological area. For instance, thin films with improved wear or corrosion resistance, improved electrical or optical properties, or simply decorative purposes are applied [1].

The first technologically important technique for deposition of functional thin films was developed in the early 1800 s when it was discovered that electrical current could reduce dissolved metal cations so that they formed a coherent metal coating. This technique, called electroplating, is still used today. Later, as vacuum technology evolved, the physical vapor deposition (PVD) techniques were developed. The perhaps first discovered PVD technique is cathodic-arc deposition which was shown by Joseph Priestley in the mid-1700s, but was seen as a curiosity without practical application at the time. The sputtering phenomenon was observed by William R. Grove in the mid-1800s [2]. Since then, the technique has advanced and is still being improved today, driven by increasing commercial demands and a desire to offer improved coatings for new applications.

\subsection{Fuel cells}

Despite the current economic crisis, the demand for energy has been continuously growing and is expected to continue growing for the coming decades due to increasing world population and economic development, especially in Asia [3]. Therefore, the development of new power generation technologies has become increasingly relevant. In that perspective, the solid oxide fuel cell (SOFC) is a technology subject to intense research as SOFCs have the potential to convert chemical energy to electrical energy with high efficiency and thereby significantly reduce $\mathrm{CO}_{2}$ emissions [4]. In addition, fuel cells are modular in design which enables decentralization of the power grid by installation of small units for domestic energy supply and thereby improve security of supply. Furthermore, a fuel cell can also be operated in the reverse mode as an electrolysis cell, to split water into hydrogen and oxygen using electricity from, e.g., a 
windmill [5]. In conclusion, fuel cell technology may become important in an energy system based on renewable energy.

The fuel cell concept has been known since the $19^{\text {th }}$ century when it was invented by Grove [6] who also described the sputtering phenomenon. Since then, different types of fuel cells have been developed. Today, the five main types of fuel cells are the alkaline fuel cell (AFC), the phosphoric acid fuel cell (PAFC), the molten carbonate fuel cell (MCFC), the polymer electrolyte membrane fuel cell (PEMFC), and the solid oxide fuel cell (SOFC). They all consist of an anode, a cathode, and an electrolyte which separates the two electrodes. Fuel cells are classified by and named after the chemical characteristics of the electrolyte but the general principle of operation is the same for all cells. The type of electrolyte dictates the operation temperature and other performance characteristics which makes different types of cells suitable for certain applications [4,7].

Earlier, research focused mostly on fuel cells working at low temperature such as PEMFC and AFC. AFCs were used in the space program in the 1960s and in the space shuttles [8], whereas today SOFC and PEMFC technologies are in focus as they are expected to have large market potential when they fully mature. PEMFCs are particularly suitable for use in passenger vehicles, such as cars and buses, due to their fast startup time, low sensitivity to orientation, and favorable power-to-weight ratio. However, they are considered to have a more long-term prospect of commercialization than SOFCs. SOFCs operate at high temperatures $\left(700-1000^{\circ} \mathrm{C}\right)$ which give them a long startup time and require significant thermal shielding. Therefore, SOFCs are not suitable for transportation in the same way as PEMFCs. Instead SOFCs aim for applications requiring continuous power/heat production such as auxiliary power units (APUs) or residential power plants where efficiencies above $80 \%$ can be reached by exploiting both the produced electricity and waste heat [9]. This thesis focuses on the SOFC technology.

Before commercialization of the SOFC technology, issues regarding scale-up, increasing lifetime of the components, and reducing the system price needs to be addressed. During the last decade research has been focused on three areas for making the SOFC technology competitive [10]. These are: (1) Cost reduction by applying conventional ceramic processing methods, simplifying production, and using low-cost technical grade raw materials. (2) Increased durability and reduced degradation of the cells which in turn also will reduce costs. (3) Increased electrochemical performance of the cells which results in higher power density and efficiency. With better performance, it becomes acceptable to lower the operation temperature which will increase cell lifetime and reduce the costs of components.

In this thesis, the route of increased electrochemical performance by use of thin films is studied. Typically, SOFC electrolytes are prepared by wet ceramic techniques such as spraying and tape-casting [10]. Deposition of thin films by physical vapor deposition (PVD) techniques is a potential way to improve the power density, as the ionic conductance through the electrolyte is inversely proportional to the layer thickness 
[11]. The use of thin film electrolytes with thicknesses down to a few micrometers can minimize ohmic losses related to the electrolyte, and reduce the operation temperature of the SOFC to an intermediate domain of $500-700{ }^{\circ} \mathrm{C}$, which will increase cell lifetime and reduce the costs of components [12,13]. Previous investigations have demonstrated laboratory-scale deposition of thin films for SOFCs by wet chemical techniques [14,15] or PVD techniques [16] such as pulsed laser deposition (PLD) [17], atomic layer deposition (ALD) [18], electron beam physical vapor evaporation (EB-PVD) [19], and magnetron sputtering [20-23].

\subsection{Objective}

The objective of this work is two-fold. The scientific objective is to study the film deposition and growth of yttria-stabilized zirconia (YSZ) and gadolinia-doped ceria (CGO or GDC) in order to prepare thin films suitable for application as SOFC electrolytes and diffusion barrier layers. The second objective is to contribute towards the commercialization of the SOFC technology by applying the obtained understanding of the material systems in an industrial context. In order to demonstrate the feasibility of large-scale deposition of thin films for SOFC application, depositions are carried out using industrial batch coating systems.

\subsection{Outline}

This thesis consists of a series of chapters that offer a background to the appended papers. Chapter 1 gives the background and sets the scope and objective of the thesis. Chapter 2 gives an introduction of the solid oxide fuel cell. In chapter 3, the principle of the magnetron sputtering techniques used to deposit YSZ and CGO is described. Chapter 4 is an overview of thin film growth. Chapter 5 gives a presentation of the analytical techniques used for materials characterization. In chapter 6 , a short introduction to fuel cell testing is given. Finally, chapter 7 is a summary of the results in the appended papers and a discussion on how my work contributes to the research field. Chapter 8 contains additional results that are relevant to the topic of the thesis. My Papers are collected at the end of the thesis. 


\section{SOLID OXIDE FUEL CELLS}

In this section, a short introduction to the SOFC is given. This includes the principle of operation, considerations for cell design, and materials used to produce SOFCs.

\subsection{Principle of operation}

The fuel cell works by converting chemical energy directly into electricity and heat. The basic building blocks of the fuel cell are an electrolyte sandwiched between a porous anode and cathode. The operation and the chemical reactions of the SOFC are sketched in figure 2.1. On the anode side fuel is continuously fed and oxidized, while on the cathode side oxygen is reduced. This creates an oxygen concentration gradient across the electrolyte, which attracts oxygen ions from the cathode side to the anode side where they react with the fuel to release electrons to the anode. These electrons pass through an external circuit back to the cathode, thereby maintaining overall electrical charge balance and producing an electric current.

The reactions are driven thermodynamically by the difference in chemical potential between the reactants and products of the overall cell reaction. The cell potential difference generated between the electrodes by the cell reactions $\left(\Delta U_{\text {cell }}\right)$ is defined by the electromotive force $(E M F)$, the potential drop associated with operation of the cell $\left(\Delta U_{\text {current }}\right)$, and voltage losses due to leaks in the cell $\left(\Delta U_{\text {leak }}\right)$ as

$$
\Delta U_{\text {cell }}=E M F-\Delta U_{\text {current }}-\Delta U_{\text {leak }}
$$

The $E M F$ is the theoretical potential difference when the current density is zero and is determined by the Nernst equation

$$
E M F=\Delta U_{\text {cell }}^{0}-\frac{R \cdot T}{Z \cdot F} \cdot \ln Q
$$

where $\Delta U^{0}$ cell is potential under standard conditions $\left(25^{\circ} \mathrm{C}, 1 \mathrm{~atm}\right), R$ is the gas constant, $T$ the temperature, $z$ the number of electrons involved, $F$ is Faraday's constant, and $Q$ the reaction quotient. The potential drop associated with operation of the cell is related to the current density and result from ohmic resistance $\left(R_{\text {ohmic }}\right)$ in the cell components and from polarization resistance $(\eta)$ due to limitations on the reaction rates. It can be written as

$$
\Delta U_{\text {current }}=i \cdot R_{\text {ohmic }}+\eta(i) \text {. }
$$


As can be seen from the above formulas, the cell potential depends on the type and composition of the supplied fuel, the cell materials, the operation temperature, and current density. The work presented in this thesis focuses on reducing the ohmic resistance of the electrolyte and the electrolyte-cathode interface in order to operate the cell at lower temperatures without loss of performance. A more thorough description of the thermodynamic principles and operation of fuel cells can be found in several textbooks and handbooks [24,25].

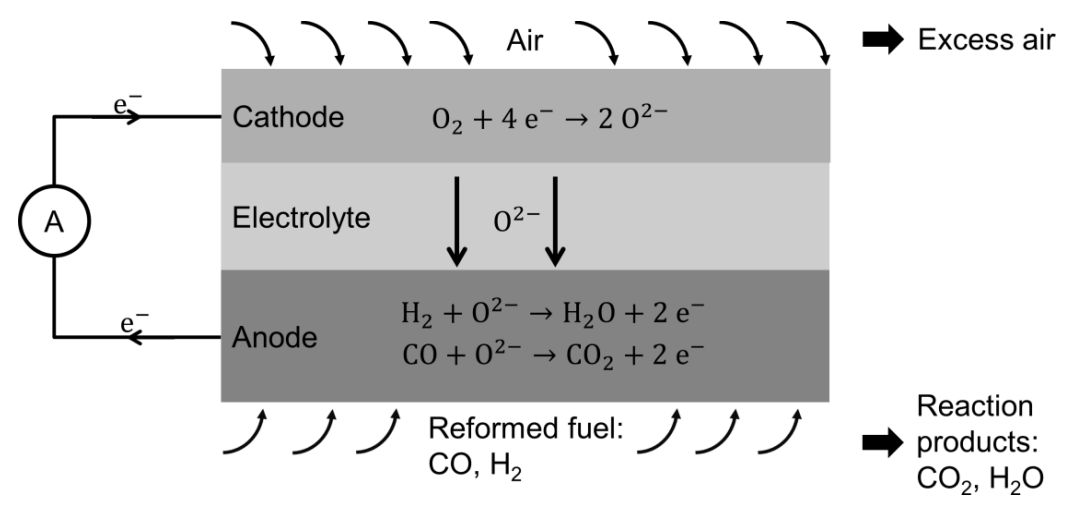

Figure 2.1: Schematic diagram showing the principle of a solid oxide fuel cell.

The SOFC uses a solid ceramic oxide as an electrolyte. The conduction of ions through the electrolyte occurs by diffusion through oxygen vacancies in the crystal lattice. Such motion is generally random but under the influence of the electrical gradient set up inside the electrolyte when the fuel cell is running a net ionic current is created. The ionic conductivity, $\sigma$, can be described by an Arrhenius equation

$$
\sigma=\frac{\sigma_{0}}{T} \exp \left(\frac{-E_{a}}{k T}\right)
$$

where $T$ is the temperature, $E_{a}$ is the activation energy for ion migration, $k$ the Boltzmann constant, and $\sigma_{0}$ is a material constant related to properties such as vacancy concentration and the charge of the carrier ions. From this equation it is clear that the ionic conductivity is highly dependent on the operation temperature. Typically, temperatures between $700-$ $1000{ }^{\circ} \mathrm{C}$ are needed in order to enable a sufficient transport of oxide ions through the electrolyte.

The SOFC is characterized by high conversion efficiencies of up to $70 \%$ [7] and the ability to run directly on hydrocarbon fuel as the high operation temperature facilitates internal reforming of hydrocarbons to $\mathrm{CO}$ and $\mathrm{H}_{2}$. It is these features, and the fact that it takes time to reach the operation temperature, that make SOFCs best suitable for 
applications such as stationary power plants where the excess heat generated in the process can be recovered [9]. Another potential use is as APUs for trucks to produce electricity more efficiently than idling the engine.

\subsection{Cell and stack design}

A typical SOFC operates at a potential below $1 \mathrm{~V}$ and delivers typically $0.5-1.5 \mathrm{~W} / \mathrm{cm}^{2}$, however, this number is highly temperature dependent and increases at higher operation temperatures $[26,16,27]$. For most practical applications, SOFCs need to be combined into a stack in order to obtain the required voltage and power output. This is done by connecting cells in series via electrically conducting interconnects. For stacking, there are two prevailing cell designs: the tubular and the planar cell. In the tubular design, the tube-shape gives the cell a high structural robustness. Tubular cells are operated with one gas inside and the other gas outside the tubes. This is another advantage as the gases are kept separated up to the point of exhaust from the cells, which yields significant benefits in sealing [24]. Planar cells have a more simple geometry making them cheaper to manufacture, easier to stack together in a compact way, and give the shortest current path $[25,28]$. This design require gas manifolds around the stack and a channel structure in the interconnect surface to allow for gas access to the electrodes without significant pressure losses. This thesis deals with planar cells whose geometry is well suited for PVD. Figure 2.2 shows a schematic drawing of the planar stack design. A short introduction to cell and stack materials is given in the following sections.

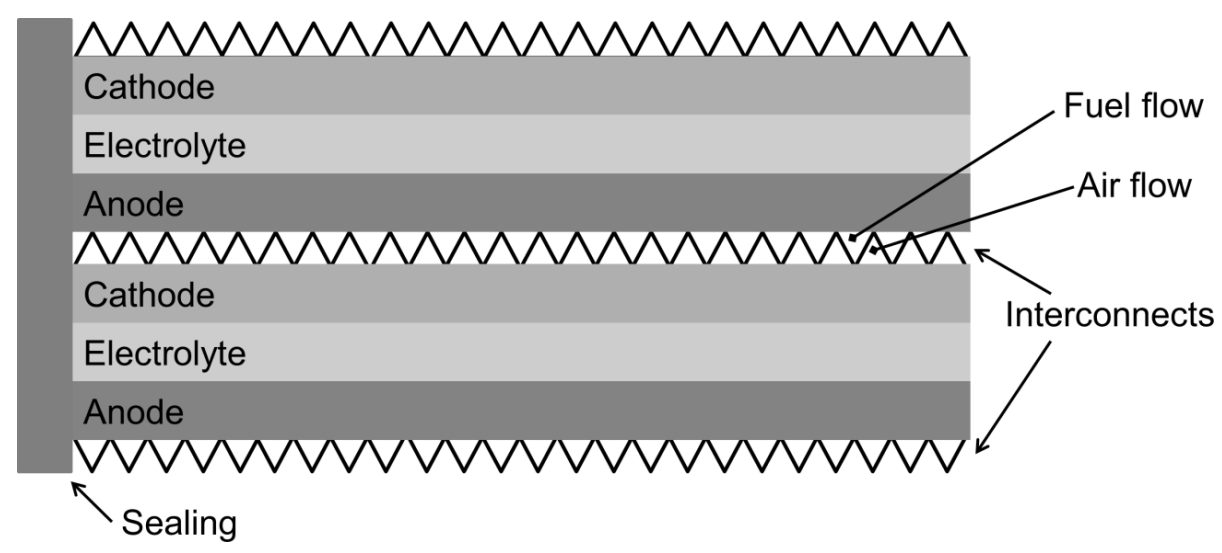

Figure 2.2: Schematic drawing of planar stack design. 


\subsection{Electrolyte materials}

It is required of the electrolyte that it be dense to separate fuel from oxygen, be electrically insulating, and be an ionic conductor. The main materials systems used for electrolytes include cation-substituted $\mathrm{ZrO}_{2}, \mathrm{CeO}_{2}$ and $\mathrm{LaGaO}_{3}$ [29]. The most widely used material is YSZ as it has a satisfactory ionic conductivity, shows good stability in both reducing and oxidizing environments, and is abundant and relatively low in cost [30]. Pure zirconia $\left(\mathrm{ZrO}_{2}\right)$ exists in three different phases. At room temperature, it is monoclinic. It transforms to the tetragonal phase above $1170{ }^{\circ} \mathrm{C}$ and to the cubic fluorite structure above $2370{ }^{\circ} \mathrm{C}$. These phase transformations are reversible and accompanied by significant volume changes. By substituting some $\mathrm{Zr}^{4+}$ ions with ions of lower valence, such as $\mathrm{Sc}^{3+}$ or $\mathrm{Y}^{3+}$, it is possible to stabilize zirconia in the cubic fluorite structure from room temperature and up to the melting point. Figure 2.3 shows the stabilization of cubic zirconia by doping with $\mathrm{Y}^{3+}$. The fluorite structure is a face centered cubic arrangement of cations with the oxygen ions occupying all the tetrahedral sites. This leaves a rather open structure with large octahedral interstitial void suitable for oxygen ion migration. The ionic conductivity is a maximum near the minimum level of dopant required to stabilize the cubic phase. Therefore, YSZ typically contains $8-10 \mathrm{~mol} \%$ yttria $\left(\mathrm{Y}_{2} \mathrm{O}_{3}\right)$ $[4,13]$. Zirconia can also be stabilized with $\mathrm{Sc}^{3+}$ ions which results in higher ionic conductivity. This can be attributed to the smaller mismatch in size between $\mathrm{Zr}^{4+}$ and $\mathrm{Sc}^{3+}$ ions, than between $\mathrm{Zr}^{4+}$ and $\mathrm{Y}^{3+}$ ions, which results in lower energy for oxygen migration, and thus higher conductivity [31]. However, the wider availability and lower price of yttria means that it is much more frequently used to stabilize zirconia. Of the same reason deposition of YSZ thin films was studied in papers $I-I I I$. In papers $V$ and VI SOFCs with zirconia electrolytes co-doped with Sc and Y were tested.

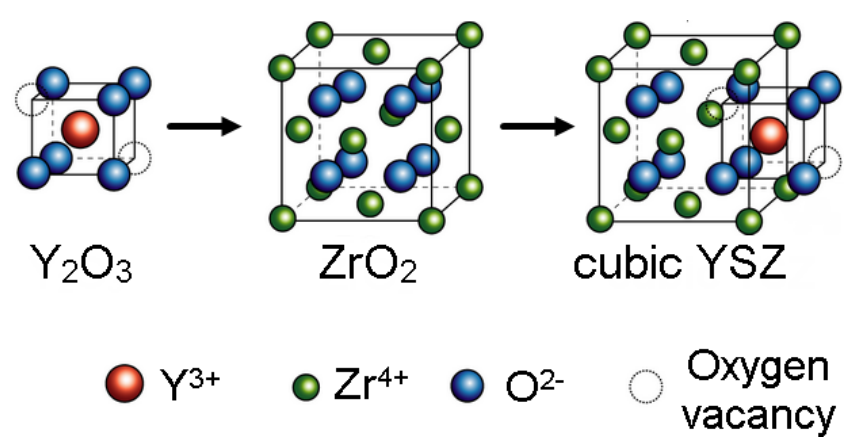

Figure 2.3: Stabilization of cubic zirconia by and introduction of oxygen vacancies. Adapted from [32]. 
CGO has also been proposed as an electrolyte material as it has a high conductivity and therefore can be used at a lower temperature relative to YSZ. Unlike zirconia, ceria $\left(\mathrm{CeO}_{2}\right)$ forms the fluorite structure over the whole temperature range from room temperature to the melting point at $2400{ }^{\circ} \mathrm{C}$. In order to achieve oxygen ion conduction, part of the $\mathrm{Ce}^{4+}$ must be substituted with a lower valence cation that introduces oxygen vacancies to maintain charge neutrality. It has been found that the high ionic conductivity is obtained when the ionic radius of the dopant is comparable to that of $\mathrm{Ce}^{4+}$ [33] and calculations have shown the ideal dopant to be $\mathrm{Sm}, \mathrm{Pm}$ or the combinations $\mathrm{Nd} / \mathrm{Sm}$ and $\mathrm{Pr} / \mathrm{Gd}$. [34]. For practical applications $\mathrm{Gd}^{3+}$ and $\mathrm{Sm}^{3+}$ doping have been extensively studied as these elements are accessible and result in high ionic conductivity. The optimum doping concentration for CGO is $10-20 \mathrm{~mol} \%$ gadolinia [35-38]. The difficulties determining the optimum dopant concentration has been coupled to differences in microstructure as bulk and grain boundary conductivity differs [29]. In this work CGO coatings with $10 \mathrm{~mol} \%$ gadolinia doping have been grown in papers $\boldsymbol{I V}-\boldsymbol{V I}$.

At temperatures of about $600{ }^{\circ} \mathrm{C}$, significant reduction of $\mathrm{Ce}^{4+}$ to $\mathrm{Ce}^{3+}$ can occur in the reducing atmosphere found on the fuel side. This reduction creates lattice stress and the CGO becomes a mixed conductor which significantly reduces its efficiency as electrolyte [35]. As this is a hindrance for the application of pure CGO electrolytes, bilayers of CGO and YSZ are often used.

\subsection{Cathode materials}

The cathode is exposed to high temperature and an oxidizing atmosphere which limits the choice of materials to noble metals and conducting oxides. The most common materials for SOFC cathodes belong to the family of perovskite-type oxides. It is possible to alter the physical and chemical properties of these materials by substituting metal ions. The cathode needs to have a high catalytic activity towards oxygen reduction, be able to conduct electrons as well as oxide ions, and have a porous microstructure to allow transport of oxygen $[4,39]$. The most commonly used cathode for zirconia-based SOFCs is $\mathrm{La}_{1-\mathrm{x}} \mathrm{Sr}_{\mathrm{x}} \mathrm{MnO}_{3}$ (LSM). When $\mathrm{LaMnO}_{3}$ is doped with $\mathrm{Sr}, \mathrm{La}^{3+}$ ions are replaced with lower valence $\mathrm{Sr}^{+2}$ ions. In order to maintain charge neutrality the concentration of $\mathrm{Mn}^{4+}$ in the $\mathrm{LaMnO}_{3}$ lattice is increased. As a result, LSM exhibits p-type conductivity [40]. As LSM is a poor ionic conductor, the cathode typically consists of a composite containing both YSZ and LSM. The YSZ phase in the composite provides the oxide ion conductivity while the LSM facilitates the catalytic activity and conducts electrons. The reaction takes place in the triple-phase boundary where the LSM, YSZ and oxygen meet. LSM-based cathodes are only satisfactorily efficient at elevated temperatures. At intermediate temperatures (around $750{ }^{\circ} \mathrm{C}$ ), polarization losses for the $\mathrm{O}_{2}$ reduction on 
the cathode are significant [41]. Other perovskite-type oxides such as $\mathrm{La}_{1-\mathrm{x}} \mathrm{Sr}_{\mathrm{x}} \mathrm{Co}_{1-\mathrm{y}} \mathrm{Fe}_{\mathrm{y}} \mathrm{O}_{3}$ (LSCF) and $\mathrm{La}_{1-\mathrm{x}} \mathrm{Sr}_{\mathrm{x}} \mathrm{CoO}_{3}$ (LSC), are suitable as intermediate temperatures cathodes as they have a high mixed ionic and electronic conduction [42]. Beside the high conductivity, the advantage of such mixed ionic-electronic conducting cathodes is that the charge transfer reactions of adsorbed oxygen atoms takes place directly and are not limited to the triple-phase boundaries. Therefore, their reactive catalytic surface area is increased. LSC has a higher ionic conductivity than LSCF; however, increases in oxygen ion conductivity and hence in mixed conductivity is generally correlated with an increasing thermal expansion [43]. Consequently, improved transport properties are linked to an increasing mismatch in thermal expansion relative to the other cell components. While LSC is still maturing, LSCF is an established alternative to LSM. A disadvantage of these types of cathodes is their incompatibility with YSZ electrodes as $\mathrm{Sr}$ and $\mathrm{La}$ from the cathode react with $\mathrm{Zr}$ from the electrolyte during operation. The reactions result in the formation of a layer of low conducting $\mathrm{La}_{2} \mathrm{Zr}_{2} \mathrm{O}_{7}$ and $\mathrm{SrZrO}_{3}$ that have a detrimental effect on the performance of the cell $[39,44]$. Therefore, a diffusion barrier layer is needed between the cathode and the electrolyte. In contrast to YSZ, CGO does not react with $\mathrm{Sr}$ and $\mathrm{La}$ from the cathode materials. This property makes CGO suitable as a diffusion barrier layer placed between the LSCF or LSC cathode and the YSZ electrolyte $[39,45,46]$. The ability of CGO barriers to prevent $\mathrm{Sr}$ diffusion is depending on layer thickness and microstructure as well as operation temperature [47]. Papers $\boldsymbol{I} \boldsymbol{V}$ and $\boldsymbol{V}$ investigate $\mathrm{Sr}$ diffusion through sputtered CGO barriers. In this thesis LSCF is applied in paper $\boldsymbol{I} \boldsymbol{V}$ while LSC is used as a cathode in papers $\boldsymbol{V}$ and $\boldsymbol{V I}$.

\subsection{Anode materials}

The most common industrially used material for SOFC anodes is a porous $\mathrm{Ni} / \mathrm{YSZ}$ cermet ${ }^{*}$. The YSZ provides oxide ion conductivity, while the catalytically active $\mathrm{Ni}$ facilitates the oxidation of the fuel. This reaction takes place in the triple-phase boundaries, where the YSZ and Ni grains meet the fuel gas. The anode requires a porosity of more than $30 \mathrm{vol} \%$ to ensure transport of fuel to the reaction sites and the removal of reaction products [48] as well as at least $30 \mathrm{vol} \% \mathrm{Ni}$ in order to be electrically conducting and function effectively as an electrode [4]. Anodes are typically prepared by sintering of a $\mathrm{NiO} / \mathrm{YSZ}$ composite followed by a reduction when exposed to the fuel gases which result in the needed porosity. Dispersion of Ni in the YSZ prevents coarsening of $\mathrm{Ni}$ particles during operation, and also gives the anode a thermal expansion coefficient comparable to that of the electrolyte. Drawbacks of Ni-based cermets include a strong volume expansion during re-oxidation which may lead to fragmentation or detachment of the electrolyte [49] and coking and sulfur contamination of the $\mathrm{Ni}$ if

\footnotetext{
A cermet is a material consisting of a mixture of metal and ceramics.
} 
hydrocarbons such as gasoline or diesel are used as fuel [50,51]. Therefore, there is an ongoing search for alternative anode materials to overcome these weaknesses. There are mainly two approaches. One is to replace $\mathrm{Ni}$ with a material less prone to carbon poisoning such as $\mathrm{Cu}$ [50]. Another is to use an oxide material as anode. Most oxide materials are immune to coking related problems. It is desired for oxide anode materials to be mixed ionic and electronic conductors, so that the electrochemical oxidation is not confined to triple-phase boundaries but extends to the solid-gas two-phase boundaries. In several cases, perovskite materials such as $\mathrm{Sr}_{1-\mathrm{x}} \mathrm{Y}_{\mathrm{x}} \mathrm{TiO}_{3}$ and $\mathrm{La}_{1-\mathrm{x}} \mathrm{Sr}_{\mathrm{x}} \mathrm{CrO}_{3}$ [50,51] have been studied for this purpose. However, these materials have still not proved to be industrially competitive to Ni/YSZ. In papers $\boldsymbol{I}-\boldsymbol{I I I}$ YSZ films have been deposited on $\mathrm{NiO} / \mathrm{YSZ}$ anodes.

\subsection{Interconnects}

When stacking SOFCs, interconnects connect cells in series electrically, and separate air at the cathode side of one cell from fuel on the at the anode side of a neighboring cell. Therefore, interconnects are required to be gas tight, have a high electronic conductivity, have a thermal expansion which matches with the expansion of other fuel cell components, and be corrosion resistant to function in both reducing and oxidizing atmospheres. Traditionally, ceramic interconnects based on doped $\mathrm{LaCrO}_{3}$ have been applied for high temperature SOFCs. By reducing the operation temperature of the SOFC to $600-800{ }^{\circ} \mathrm{C}$, steel-based metallic interconnects can be used instead. Compared to ceramic interconnects, these interconnects provide mechanical support, are easier to process, and cheaper [52]. However, the shift to metallic interconnects also include some challenges in the form of preventing corrosion of the metal which result in increased resistance, and the evaporation of $\mathrm{Cr}$ from the alloy which can poison the cathode with Cr species [53].

\subsection{Sealing}

SOFCs in the planar configuration require several seals. Gastight seals must be applied along the edges of each cell, along the outer edges of the stacking layers, and at the gas manifold in order to separate the gas compartments and to insulate the stacking layers from each other. The sealing material needs to be electrically insulating, stable towards all other cell components as well as the atmospheric conditions. In order to obtain a tight seal, a match between the thermal expansion coefficients of the seal and the cell components as well as a degree of deformability is essential. For SOFCs, seals are typically glass-based [54]. 


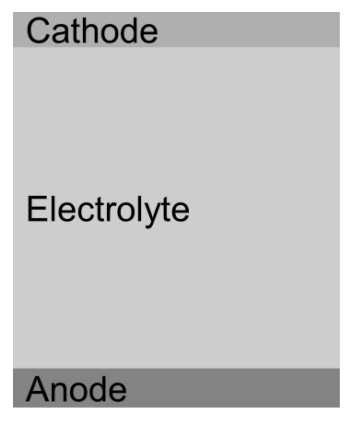

$1^{\text {st }}$ generation cell, Electrolyte-supported

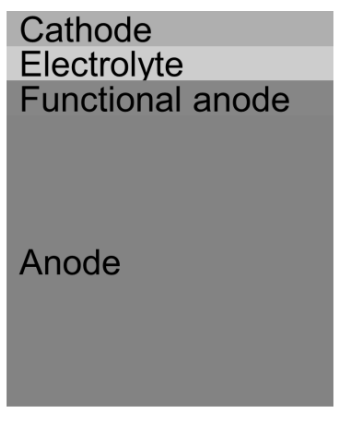

$2^{\text {nd }}$ generation cell, Anode-supported

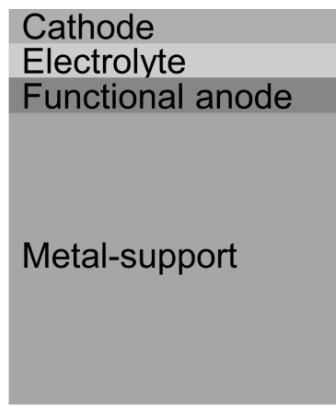

$3^{\text {rd }}$ generation cell, Metal-supported

Figure 2.4: Sketch of the three generations of planar cells.

\subsection{Structural support of the cell}

Three designs for bringing structural support and mechanical strength to the planar cell have been developed. These designs are based on electrolyte-, anode-, and metal-support and are known as first, second, and third generation cells, respectively. Sketches showing the three designs are seen in figure 2.4. The first developed design was based on a hundreds-of-micrometers thick electrolyte to support the cell. As a consequence, operation temperatures around $1000{ }^{\circ} \mathrm{C}$ were needed to obtain reasonable performance. Other cell components, such as interconnects, capable of operating in this temperature range are complex and expensive which makes lower temperatures desirable. The second generation cell is based on anode-support. In this design, the anode is divided into a functional top layer $(<50 \mu \mathrm{m})$ and a thick supporting layer. This design allows for thin electrolytes and can operate at temperatures below $800{ }^{\circ} \mathrm{C}$. The third-generation design utilizes thin ceramic functional layers for the anode and a robust porous metal layer beneath the anode functional layer for mechanical support. Compared to cells based on ceramic support, this design provides substantial advantages with respect to materials and manufacturing costs as well as improved mechanical properties. For some applications, such as APUs, the improved robustness and tolerance to dynamic operation, including fast start-up, thermal cycling, and shock vibrations are important [55]. Due to the metalsupport, third generation cells are intended to operate at temperatures below $800{ }^{\circ} \mathrm{C}$ in order to prevent corrosion of the metal. The fabrication of metal-supported SOFC has been more challenging than fabrication of ceramic cells as sintering is required to be carried out in reducing atmosphere, to avoid corrosion of the steel component. Furthermore, the conventional Ni/YSZ anode is not compatible with co-sintering in 
reducing atmosphere which results in $\mathrm{Ni}$ coarsening and $\mathrm{Ni}-\mathrm{Fe}-\mathrm{Cr}$ interdiffusion and consequently decreased performance and material stability. Therefore, it must be infiltrated to the active anode later in the process $[55,56]$. Also, the conventional cathodes such as LSM and LSCF cannot be transferred directly to metal-supported SOFCs as these typically require sintering at temperatures above $1000{ }^{\circ} \mathrm{C}$ to bind properly to the electrolyte which is too high temperature for the metal-support [55].

In this work, YSZ electrolyte coatings have been deposited on anode-supported cells (papers $\boldsymbol{I}-\boldsymbol{I I I}$ ) and CGO barrier coatings have been deposited on electrolytes on metal-supported cells (papers $\boldsymbol{V}$ and $\boldsymbol{V I}$ ). In paper IV, CGO and YSZ depositions have been carried out on LSCF cathodes. 


\section{FILM DEPOSITION}

Several techniques exist for thin film synthesis. These include electroplating [57], cathodic-arc deposition [58], sputter deposition [59], chemical vapor deposition [60], and combinations of these methods. All are widely used in industry and have consequently been extensively studied. PVD techniques, such as sputtering, are characterized by simplicity and a high degree of flexibility. The evolution of the sputtering techniques is far from over and these years new techniques, such as high power impulse magnetron sputtering (HiPIMS), are moving out of the lab and into production halls. The following chapter is intended to give a short introduction to the sputtering technique and the physics of sputtering.

\subsection{The principle of sputter deposition}

In a sputtering process, atoms are ejected from a target material due to bombardment by energetic particles. Figure 3.1 shows a schematic drawing of a sputtering system. Inside a vacuum chamber, two electrodes are placed. Typically, the chamber walls will act as anode whereas a target, made of the material to be deposited, is connected to the negative terminal of a power supply and serves as the cathode. The object to be coated (the substrate) is placed in front of the target. The substrate can be biased or at a floating potential.

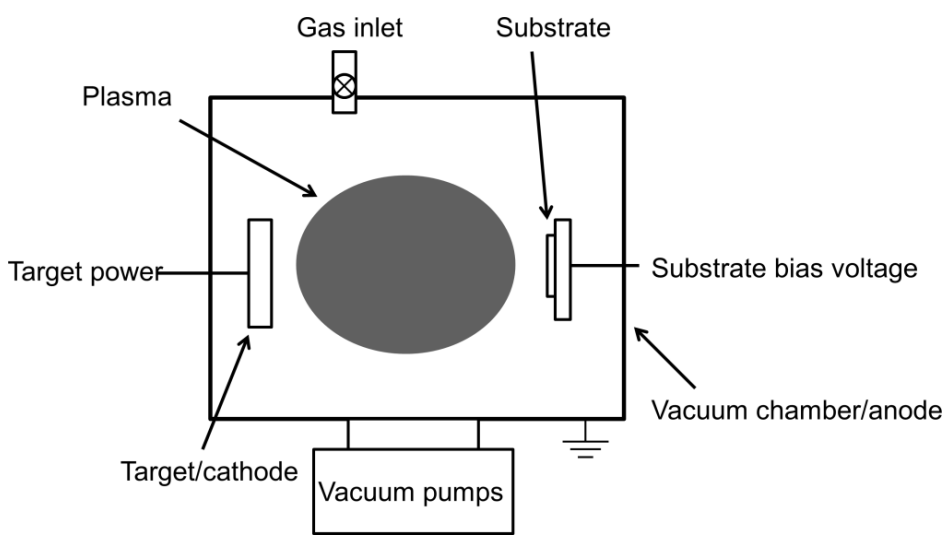

Figure 3.1: Schematic drawing of a sputtering system.

To form plasma, an inert working gas such as argon is introduced into the chamber. $\mathrm{Ar}^{+}-$ ions of the working gas are accelerated towards the target by the electric field between the electrodes. Upon impact, neutral atoms will be ejected from the target through 
momentum transfer from the energetic $\mathrm{Ar}^{+}$-ions. The sputtered atoms pass through the discharge and condense onto the substrate to grow a film. Besides sputtering of neutral atoms, the impacts also eject secondary electrons. These electrons collide with the neutral gas atoms and form more ions which return to the cathode. Thus, the plasma becomes self-sustaining when the number of ejected secondary electrons is sufficient to produce the required ions.

\subsection{DC glow discharge}

A plasma is a quasi-neutral gas of charged and neutral particles characterized by a collective behavior [61]. Quasi-neutrality means that there are equal amounts of ions and electrons, in addition to the neutral particles, and the overall charge is zero. The plasmas encountered in DC sputter deposition are typically formed at pressures in the range 0.1 $10 \mathrm{~Pa}$ and have a low degree of ionization, typically $10^{-4}$ [58]. For sputtering plasmas, the name glow discharge is often used because of the light emitted when atoms excited by collisions in the plasma lose their energy.

When a DC voltage from a high-impedance power supply is first applied to electrodes immersed in a low pressure gas, the low number of charge carriers present in the gas will yield a low current. If the voltage is increased, the charged particles will receive enough energy to generate more carriers through impact with neutral gas atoms and ion collisions with the cathode, which release secondary electrons. The secondary electrons are accelerated away from the cathode by the electric field and ionize the working gas by inelastic collisions which result in the formation of a new ion-electron pair. The newly formed ions will be accelerated back towards to cathode and the formation of a new secondary electron is possible. This charge multiplication makes the current increase rapidly, while the voltage is constant due to the high impedance of the power supply. This regime is known as the Townsend discharge, see figure 3.2.

As the number of ejected secondary electrons increases further, these will eventually produce enough ions to regenerate the same number of initial electrons. When this happens, the discharge becomes self-sustainable and starts to glow, the voltage drops and the currents rises abruptly. This is known as the normal glow region. At first, the ion bombardment will be confined to surface irregularities and edges but by further increasing the power the bombardment will spread out and cover the entire cathode. If the power is further increased the result will be higher voltage and current densities. This region is called the abnormal discharge and it is in this domain sputter deposition is carried out.

Not every ion-cathode collision results in the emission of a secondary electron. Therefore, in order to sustain the plasma, the probability of collisions between the neutral gas atoms and the electrons has to be sufficiently high. If the pressure in the chamber is 
too low, the mean free path of the electrons will become long and the probability for collisions too low. The electrons will be lost to the chamber walls and the plasma will not be able to sustain itself. On the other hand, if the pressure is too high the frequent collisions will prevent the electrons from gaining enough energy to ionize gas atoms and the discharge will be quenched. For a simple DC sputtering setup, the optimum pressure is typically in the range of $0.1-10 \mathrm{~Pa}$. In this range, the discharge can be sustained at voltages in the range of $200-1000 \mathrm{~V}$ [58].

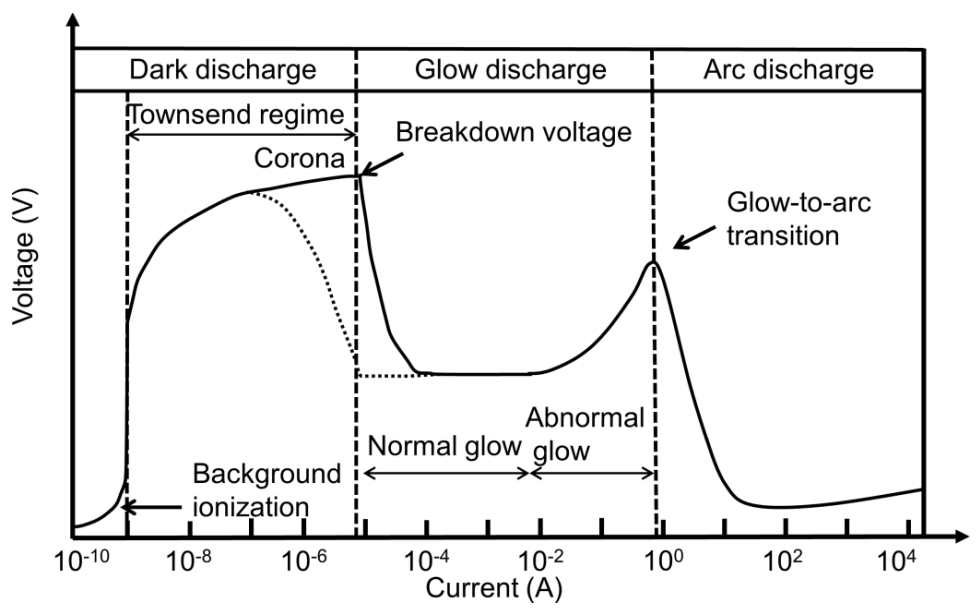

Figure 3.2: The formation of DC glow discharge. Adapted from Roth [62].

Because of their lower mass, the electrons in the discharge have a much higher mobility than the ions and will tend to reach the borders of the discharge at a much faster rate, compared to the ions. Any isolated surface immersed in the plasma will therefore start charging negatively. As the negative charge builds, additional electrons are repelled, positive ions are attracted, and the rate at which the surface is charging decreases. Ultimately, the electron flux will equal the ion flux and the net current will be zero. The surface will be at potential slightly negative with respect to ground, known as the floating potential. For the same reason, the plasma itself will be at a slightly positive potential, which is known as the plasma potential. If the immersed surface is negatively biased the negative bias replaces the floating potential. The voltage distribution in the DC glow discharge is shown in figure 3.3. Around each of the electrodes, regions with a net positive space charge develop. These regions are called the anode sheath and cathode sheath. The electric fields in the plasma are restricted to these sheath regions. As the cathode is at a negative potential in order to attract positive ions, almost the entire potential difference between the electrodes is confined to the cathode sheath. When the ions are accelerated through the cathode sheath they gain a maximum kinetic energy of $\mathrm{e}\left(\mathrm{V}_{\mathrm{P}}+\mathrm{V}_{0}\right)$, see figure 3.3, before impact with the cathode. 


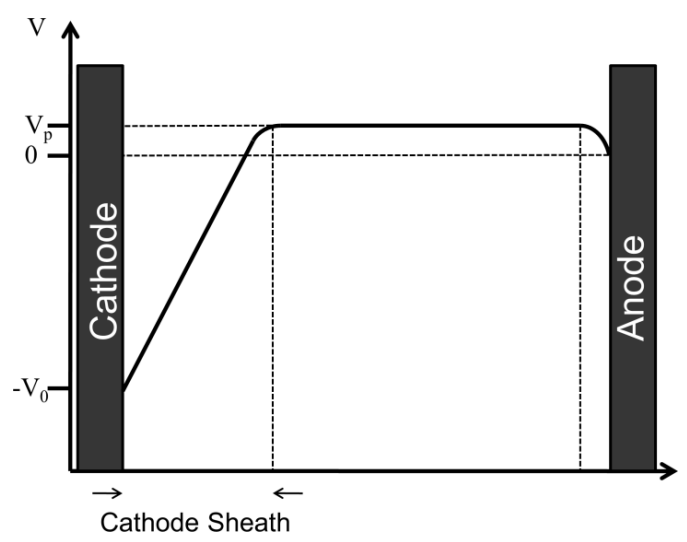

Figure 3.3: Schematic voltage distribution across a DC glow discharge. Adapted from Ohring [58]

\subsection{The sputtering phenomenon}

When the positive ions impact with the target, several interactions can occur. As seen in figure 3.4, the ion can be implanted, recoil away from the target, or cause the important generation of secondary electrons. However, the intended process is the ejection of a target atom. Sputtering is the result of momentum transfer from the incoming ion to the target atoms through a collision cascade in the near-surface region of the target. The average number of target atoms sputtered per incident ion is known as the sputtering yield. The sputtering yield depends on the mass of the incident ions and target atoms, the kinetic energy of incident ions, the heat of sublimation of an atom at the target surface, and the incidence angle of the ion [63]. It is generally desired to have a high sputtering yield as it results in a high sputter rate and consequently high deposition rate. Sputtering yields are typically measured to be between 0.1 and 5. For Ce, Gd, Y, and $\mathrm{Zr}$ the sputtering yield is in the range $0.6-0.9$ for Ar hitting the target perpendicularly at 500 $\mathrm{eV}$ [64]. In general, the sputtering yield of oxides is lower than the sputtering yield of pure metals due to their higher heat of sublimation. Therefore, when depositing oxide thin films it is often chosen to sputter metallic targets and let the thin film fom by reaction with oxygen on the substrate surface. In this way higher deposition rates can be achieved if the formation of an oxide layer on the target can be prevented. In this thesis, all thin films have been prepared by reactive sputtering of metal targets. Reactive sputtering is further discribed in section 3.6. 


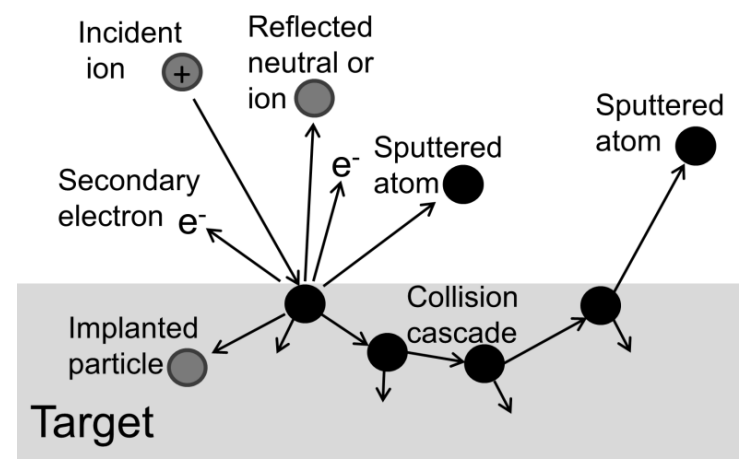

Figure 3.4: Processes that occur at the target when hit by an incident ion.

Not all sputtered atoms are transported to the substrate and the growing film as they may collide with sputtering gas molecules and be scattered. The effects of scattering can be described by the mean free path which is the average distance an atom will travel before it collides and scatters. The mean free path is dependent on parameters such as pressure, temperature, and molecular diameters and masses of the species. When the sputtered species leave the target they have an initial kinetic energy. Some of this kinetic energy will be lost in each collision with sputtering-gas molecules and after several collisions the sputtered species will have lost all of their initial kinetic energy. In that case, the sputtered particle is said to have been thermalized and the motion of the particle is random. At $0.5 \mathrm{~Pa}$ the mean free path is typically around $5 \mathrm{~cm} \mathrm{[59]} \mathrm{which} \mathrm{is} \mathrm{in} \mathrm{the} \mathrm{same}$ range as the target-substrate distance most often applied. Therefore the species can still be carrying some kinetic energy or be fully thermalized when they arrive at the substrate. It is often sought that the flux of sputtered species has not lost all of the kinetic energy as the energetic particles gives higher adatom mobility and denser film. However, the low sputtering-gas pressure required for the particles to remain in the fully ballistic regime is often associated with low sputtering rate. Sometimes the required pressure may even be so low that the plasma cannot be sustained. Hence, most sputtering processes are operated in a transition regime where the flux is not fully thermalized.

\subsection{Effects on the substrate}

Compared to deposition by thermal evaporation, sputtered atoms are more energetic when impinging on the substrate, and hence have higher adatom mobility. A way commonly used to influence the adatom mobility and film nucleation rate is the application of a substrate bias voltage which can result in altered film structure and properties [65]. By applying a negative bias voltage to the substrate, positive ions entering the sheath region at the substrate will be accelerated towards the growing film. 
In this way, the average energy of the particles arriving on the substrate surface can be substantially increased. The bombarding ions transfer energy and momentum to the atoms in the film surface and thereby provide atomic scale heating and higher adatom mobility. However, when high bias voltages are applied to the substrate resputtering can occur. In this case the substrate itself acts as a sputtering target and newly condensed species can be sputtered away. High bias voltages may also result in implantation of working gas ions in the growing film and/or increased defect formation in the crystal lattice.

Applying a positive substrate bias voltage results in electron bombardment which typically leads to heating of the substrate and hence also can be used for film modification. When depositing insolating films a pulsed bias voltage consisting of asymmetric positive and negative voltage polarities is applied. During the positive portion of the cycle, electrons are drawn to the film in order to neutralize the positive charge buildup that otherwise would cause arcs.

Cathodic-arc deposition and high power impulse magnetron sputtering (HiPIMS) are characterized by a high degree of ionization of the deposition species. Therefore, application of substrate bias can be used to steer the ionized flux to the substrate when depositing by these techniques.

\subsection{DC magnetron sputtering}

Magnetron sputtering is one of the most widely used commercial techniques for thin film deposition. The use of a magnetron can significantly increase the deposition rate and reduce the operating pressure of the system compared to a setup without a magnetron.

The idea behind magnetron sputtering is to place permanent magnets behind the target in a suitable configuration so that the magnetic field is applied parallel to the target and perpendicular to the electric field. This is shown schematically in figure 3.5. This magnet configuration traps electrons near the target surface and thereby increases the degree of ionization. The electrons are subject to the Lorentz force

$$
\boldsymbol{F}=m \frac{d v}{d t}=e(\boldsymbol{E}+\boldsymbol{v} \times \boldsymbol{B})
$$

where $m$ is the electron mass, $e$ the electronic charge and $\boldsymbol{v}$ is the electron velocity. $\boldsymbol{B}$ and $E$ are the electric and magnetic fields, respectively. Electrons emitted at an angle slightly off the target normal will execute a helical motion along the magnetic field normal to the target. When reaching the region of the magnetic field parallel to the target the electrons are forced to move in an orbit back to the target. Solving the equations of motion, the electrons are found to move in cycloidal trajectories near the target. 


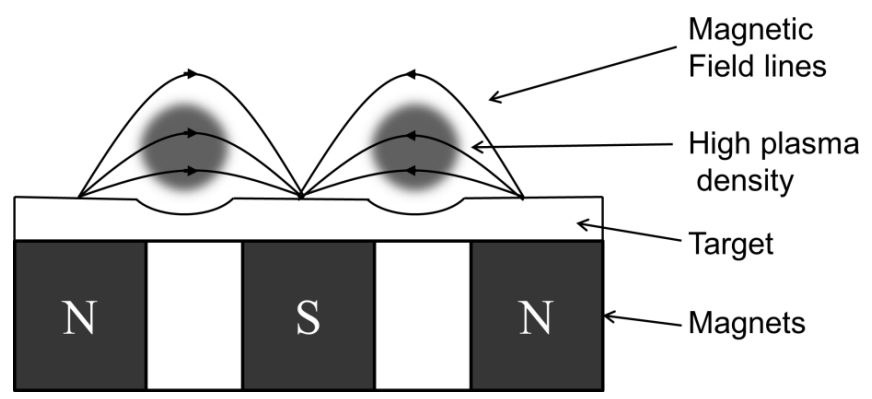

Figure 3.5: Schematic drawing of a magnetron configuration.

Generally, the magnetic field prolongs the residence time of the electron in the plasma, resulting in more collisions with the gas atoms, before being lost to the chamber walls. The result is an increased ionization of working gas atoms, leading to a higher sputtering rate. By suitable orientation of the magnets, a region known as the race-track can be defined. In the race-track region the electrons hop around at high speed, efficiently ionizing the working gas. Therefore, sputtering is going on at the highest rate in this region, resulting in a characteristic erosion profile. This irregular erosion is one of the drawbacks of magnetron sputtering. Traditionally, only $20-30 \%$ of the target material has been utilized before the target had to be replaced. However, the development of improved magnet configurations has resulted in better utilization of the target, especially in industrial systems.

Depending on the design of the magnetron, the strength of the central magnet can be the same as or different from the outer magnets. If the field strengths of all magnets are the same, all of the magnetic lines from outer magnets end up in the central magnet or vice versa as in the example in figure 3.5. But if the strengths of the magnets are not the same, the magnetron will be unbalanced and the electrons are allowed to escape. In that way the plasma can be extended towards the substrate and be used to influence film growth. Therefore, unbalanced magnetrons are the most used configuration. When applying more targets, unbalanced magnetrons are often arranged in a way where the escaping field of the south pole of one magnetron is opposite the north pole of the other magnetron. This dual arrangement aids in trapping the escaping electrons and is used in papers $I$ and $I I I-V I$.

\subsection{Reactive sputtering}

Reactive sputtering is the sputtering of an elemental or alloy target in the presence of a gas that reacts with the sputtered atoms and forms a compound. This is a useful technique that is widely applied for deposition of oxides, nitrides, and carbides. The reaction 
between the atoms and the reactive gas mainly occurs on surfaces. The reason it that atomic constituents cannot combine in two-body gas-phase collisions because the diatomic molecule formed cannot conserve both energy and momentum [66]. This means that both the substrate and the target can be covered with a compound film. The reaction on the target is the source of a traditional problem in reactive sputtering. The sputtering yield of a compound is usually much lower than the sputtering yield of corresponding element. When the partial pressure of the reactive gas is so high that compound formation occurs faster than material can be sputtered away, the target gets covered with a compound film. It is then said to be poisoned. The resulting deposition rate will be low, but the films will be stoichiometric. If, on the other hand, the partial pressure is low or the sputter rate is high the atoms can be sputtered away from the target faster than a compound can be formed. The result is a high deposition rate but commonly understoichiometric films. This mode of deposition is called metallic mode. The transition from metallic to poisoned mode is often abrupt, and the increase in total pressure is accompanied by significant changes in cathode voltage and current when operating in constant power mode. Furthermore, the reactive gas flow must be decreased well below the transition onset point to remove the compound formed on the target. This hysteresis effect is shown in figure 3.6 for the deposition of YSZ as in paper I.

Often a partial pressure is chosen so the deposition takes place at the transition from a metallic target to a poisoned target, as this mode will result in stoichiometric films and a reasonable deposition rate. The transition region is, however, unstable and a feedback control of the partial pressure is required. Today, the basic feedback systems commonly used to control the partial pressure are an optical emission spectrometer, an integrated mass spectrometer, a lambda sensor (for $\mathrm{O}_{2}$ only), or the use of the cathode voltage as a feedback mechanism [67]. The latter can be used in a feedback loop as the shift from metallic to poisoned mode is associated with a drop in cathode voltage when running at constant power as seen in figure 3.6.b. The reason is a higher secondary electron emission coefficient for the compound than the elemental/alloy target.

All reactive pulsed DC magnetron sputtered films presented in this thesis have been deposited in the transition region and a feedback loop based on cathode current and voltage has been applied. Therefore, curves as the one shown in figure 3.6.b had to be determined before depositions were carried out. 

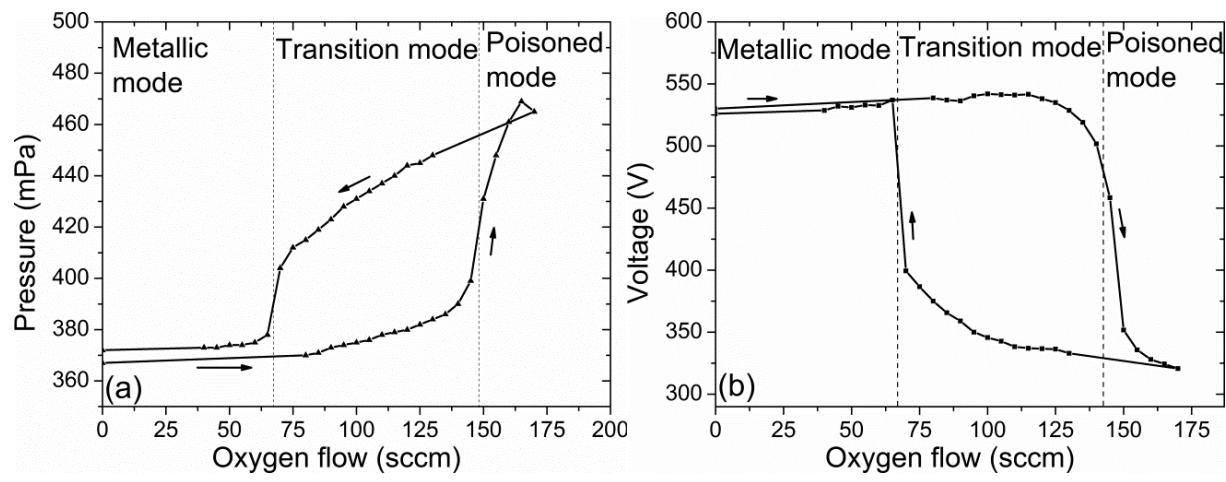

Figure 3.6: Pressure (a) and voltage hysteresis curves measured for the deposition of YSZ.

\subsection{Pulsed DC magnetron sputtering}

As mentioned above in the discussion of reactive sputtering, reactive gases often form dielectric coatings on metal target surfaces. The positive ions bombarding the target cannot be neutralized by the electrons from the target because of the formation of an isolating film. When this happens, a positive charge starts to buildup on the surface, and may eventually become as large as the dielectric breakdown value of the compound layer. The result will be arcing, where much of the discharge current is concentrated on a small surface area of the target and a subsequent ejection of macro-particles from the target, leading to inhomogeneities and defects in the film [68].

Pulsation of the voltage supplied to the sputtering targets is the solution to prevent charging and arcing. The basic principle is that positive charging of the target can be avoided be discharging the surface by bombarding it with electrons. The voltage pulses can either be square or sinusoidal with applied frequencies of several kilohertz. Two common ways of discharging the target are switching the voltage to ground (unipolar) or switching to a slightly positive voltage (bipolar). The high mobility of the electrons is the reason for choosing only a slightly positive value, typically $10 \%$ of the numerical value of the negative bias, to discharge in the bipolar mode. After discharging, the target is negatively powered and sputtering takes place.

\subsection{High power impulse magnetron sputtering (HiPIMS)}

There are a number of ways to increase the plasma density and thereby the ion flux when sputter depositing thin films. Some techniques increase the ionization of the atoms by post-vaporization ionization using radio-frequency or magnetic coils to generate ions. Another possibility is the use of hollow cathode magnetron sputtering. In this setup a 
cylinder or two parallel plates confine the discharge both physically and electrostatically. It works like two electrostatic mirrors reflecting electrons between the sheaths until they are thermalized through collisions, thus increasing the plasma density [69].

A fairly new development is $\mathrm{HiPIMS}^{\dagger}$ deposition [70] which has been made commercially available within the last decade. This technique is based on conventional DC magnetron sputtering but the power supply to the target has been exchanged with a pulsed high-power supply rather than the traditional DC supply. With pulse frequencies less than $10 \mathrm{kHz}$ and duty cycles less than $10 \%$, pulse power densities in the order of $\mathrm{kW} / \mathrm{cm}^{2}$ are achieved and as a result a dense and highly ionized plasma is created $[69,71]$. The low duty cycle provides sufficient time for target cooling between the pulses and the average power is comparable to the ones measured in conventional DC magnetron sputtering. Due to the high plasma density, a large fraction of the sputtered flux (over $90 \%$ for metals) can be ionized [72]. The flux of ionized species can be drawn to the substrate and modify the properties of the growing film as described in section 3.4. Several reports show a change in film morphology toward denser, featureless films when applying HiPIMS compared to DC magnetron sputtering [71,73-75]. This is the kind of morphology that is desired in the fabrication of SOFC electrolytes which is the reason for exploring HiPIMS deposition of YSZ in papers II and $\boldsymbol{I I I}$.

An issue with the HIPIMS technique is the low deposition rate in comparison with DC magnetron sputtering. One explanation for the reduced deposition rate is backattraction to the target of ionized sputtered particles. Another is that sputtered material is deposited perpendicular to the target surface and in that way lost for the substrate placed parallel with the target. It is likely that a combination of several factors is the cause [76]. The reduced deposition rate has raised concerns about lost productivity. However, one can argue that in some applications the advantages of HIPIMS justify the reduced productivity as it becomes possible to achieve film properties that normally cannot be obtained by DC sputtering.

\subsection{Optical emission spectroscopy}

Characterization of the plasma is often of importance in order to understand the film synthesis process and explain film properties. This is especially important when performing HiPIMS depositions as the plasma conditions can be significantly changed by tuning the pulses. A number of instruments and methods exist for the study of the plasma such as Langmuir probes for measuring electron temperatures, densities, and plasma potentials, and mass spectroscopy to study the kinetic energy of the ionic species [77]. However, optical emission spectroscopy (OES), which can be used to study the population of ions and neutrals in the plasma, is one of the most commonly used

\footnotetext{
${ }^{\dagger}$ Sometimes referred to as high power pulsed magnetron sputtering, HPPMS
} 
techniques. This is related to the fact that it does not interfere with the plasma itself and is often applied to run a feedback loop to perform reactive sputtering in the transition region (see section 3.6). It is the only technique applied for plasma characterization in this thesis.

The excited atoms and ions in the plasma create unique emission spectra specific to each element which are collected by the spectrometer and presented as shown in figure 3.7 for the case of YSZ. The spectra can be complex when several elements and possibly molecular species are present in the plasma. Each line in the spectra relates to a transition from an excited or charged state and the spectrum therefore shows both which species are present in the plasma and if they are ionized or not. Changes in the ratio between the line intensities can be used as a measure of a change in the ratio of species, both ionic and neutral, in the plasma. OES was used in paper III to study the ionization of sputtered species during HiPIMS deposition.

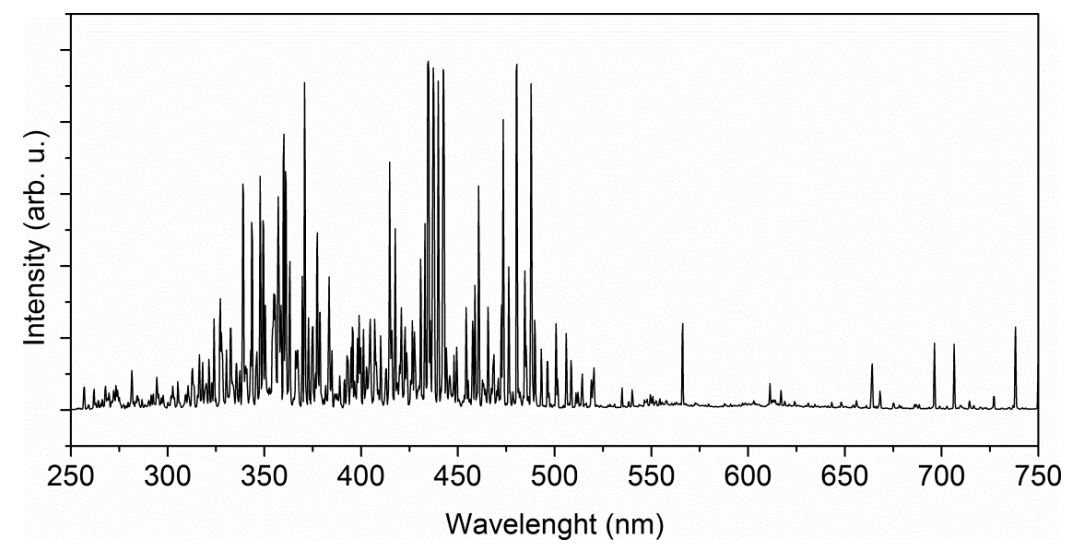

Figure 3.7: OES spectrum of the plasma during HiPIMS deposition of YSZ.

\subsection{Setup}

Three different sputter systems have been used to prepare the coatings presented in this thesis. Two of the systems were industrial-scale units from CemeCon AG, Germany, while one was a smaller lab-scale system.

The two CemeCon units were both based on CemeCon's CC800/9 ML platform seen in figure 3.8. One unit was optimized for pulsed DC magnetron sputtering (SinOx unit [78]) whereas the other unit was capable of HiPIMS deposition. The SinOx unit was applied in papers $\boldsymbol{I}$ and $\boldsymbol{I} \boldsymbol{V}-\boldsymbol{V I}$ while the HiPIMS unit was used in paper $\boldsymbol{I I I}$. The units had a chamber size of $850 \times 850 \times 1000 \mathrm{~mm}$ and were able to cover substrates at a maximum size of $400 \mathrm{~mm}$ in diameter and $400 \mathrm{~mm}$ in height. Up to four targets $\left(88 \times 500 \mathrm{~mm}^{2}\right)$ could be mounted in the chamber in the SinOx unit, while the HiPIMS unit could mount up to six targets of which only two could be run in HiPIMS mode. The 
positions of the targets are shown in figure 3.9. When depositing by pulsed DC magnetron sputtering only to targets in on side was used. Also, in the HiPIMS depositions only the two HiPIMS cathodes were used. Substrates were mounted in the center of the chamber on a rotating mounting platform that carried out a 2-fold (papers $I$ and $\boldsymbol{I V}-\boldsymbol{V I}$ ) or 1-fold (paper $\boldsymbol{I I I}$ ) planetary rotation. The systems were equipped with two turbomolecular pumps and a rotary vane type backing pump to reach a base pressure below $1 \mathrm{mPa}$. Ar (99.999\%) and $\mathrm{Kr}(99.999 \%)$ were used as working gases while $\mathrm{O}_{2}$ $(99.999 \%)$ was supplied as a reactive gas for oxide formation. The flow rates of the gases were regulated by mass-flow-control units.

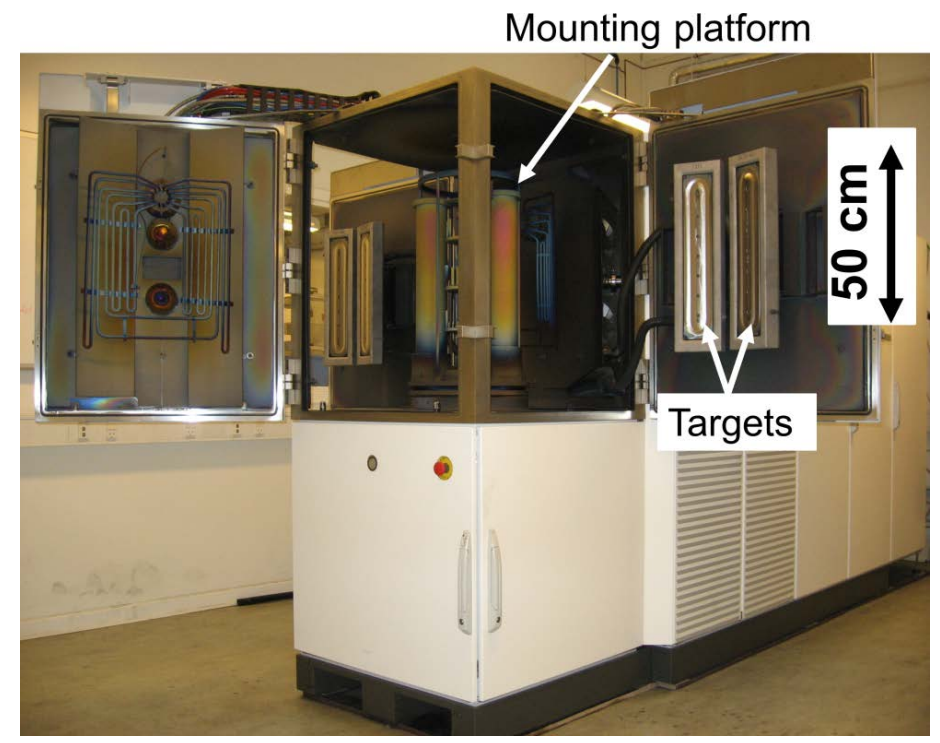

Figure 3.8: Photograph of the CC800/9 coating unit from CemeCon.

When depositing with the $\mathrm{SinOx}$ unit, the $\mathrm{O}_{2}$ partial pressure was controlled through a cathode current feedback mechanism to gain a stable deposition of the oxide thin film. Before using this feedback mechanism, the hysteresis behavior of the system needed to be determined at the conditions chosen for the deposition as discussed in section 3.6. During deposition, the system was operated a constant cathode voltage, known to result in deposition in the transition region when operating at a certain target power. A cathode current set-point was chosen to obtain the sought cathode power. Changes in the oxygen partial pressure resulted in changes in the cathode current away from the set-point due to compound formation or removal on the target surface. The feedback loop regulated the oxygen to bring the current back to the set-point. The targets were operated in unipolar dual-magnetron mode with a repetition frequency of $50 \mathrm{kHz}$ 
and a duty cycle of $50 \%$. Substrate bias voltage was applied as an asymmetric bipolar pulse with a repetition frequency of $350 \mathrm{kHz}$ and a positive pulse set to $10 \%$ of the numerical value of the negative bias.

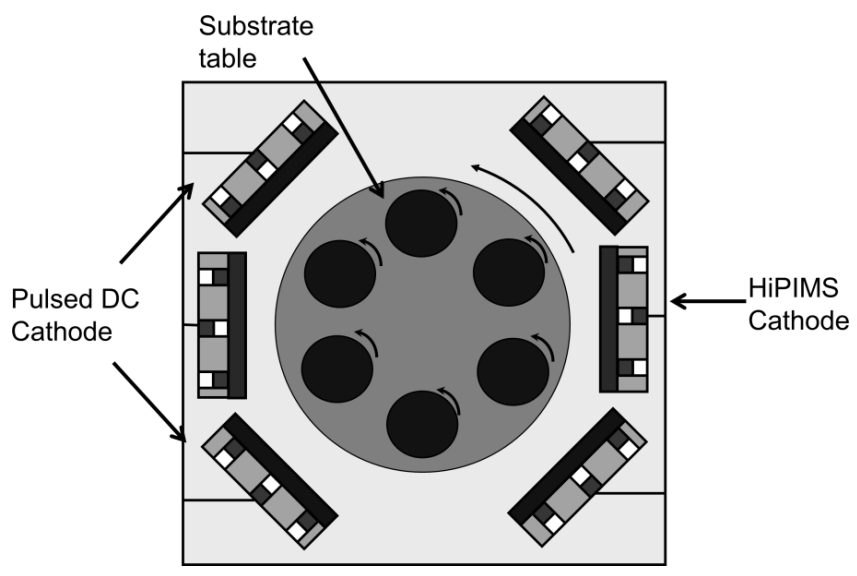

Figure 3.9: Schematic drawing of targets position in the CemeCon HiPIMS unit seen from above. In the pulsed DC unit the positions of the DC cathodes are the same.

HiPIMS depositions in the CemeCon unit were carried out at a constant power in poisoned mode as no feedback system was installed to control the $\mathrm{O}_{2}$ partial pressure and maintain steady deposition in the transition region. The repetition frequency could be altered in steps of $100 \mathrm{~Hz}$ from a maximum of $1 \mathrm{kHz}$ and the pulse length could be changed in steps of $10 \mu \mathrm{s}$ from a maximum of $200 \mu \mathrm{s}$. The repetition frequency and pulse length were tuned in order to obtain a stable window of operation. During the processes, the voltage and current waveforms at the cathodes, as well as the substrate table, were recorded from an oscilloscope (Tektronix, DPO 2024). The two HiPIMS cathodes as well as the substrate table could be operated simultaneously in a synchronized HIPIMS mode were the bias was applied to the substrate at the same time as the HiPIMS pulses to the targets. More information on the CemeCon units can be found on CemeCon's homepage [78].

The lab-scale equipment used in paper $\boldsymbol{I I}$ was equipped with a circular $50 \mathrm{~mm}$ magnetron with the substrates positioned directly beneath the target at a stationary substrate holder at a distance of $7 \mathrm{~cm}$. Ar and $\mathrm{O}_{2}$ gas flows were controlled by electronic mass flow controllers while the total process pressure was controlled by a gate valve. Depositions were made by both pulsed DC magnetron sputtering as well as HiPIMS. In the case of pulsed DC magnetron sputtering, the power to the cathode was applied by a DC plasma generator (ENI RPG-50) operating at a frequency of $150 \mathrm{kHz}$ with $40 \%$ duty cycle. In the case of HiPIMS, the power to the cathode was applied in the form of 
unipolar pulses with a repetition frequency of $500 \mathrm{~Hz}$ and a width of $35 \mu$ s resulting in a duty cycle of $1.75 \%$. The power was supplied by a pulsing unit (SPIK 1000A, Melec) fed by an MDX $1 \mathrm{~K}$ direct current generator (Advanced Energy) operated in constant power mode. The discharge voltage and current were monitored with a Tektronix TDS 520C oscilloscope. A pulsed substrate bias was supplied to the substrate using a homedesigned pulsing unit operating at a frequency of $200 \mathrm{kHz}$. 


\section{THIN FILM GROWTH}

In the previous chapter, sputtering of material was described. This chapter deals with the arrival of the sputtered species at the substrate and the process of film growth.

\subsection{Nucleation and growth}

When the sputtered species arrive at the substrate, they are mobile and start moving around on the surface. Eventually, several adatoms meet in a cluster. Nucleation only occurs when it results in a reduction in the total free energy which means the cluster needs to reach a critical size before nucleation. Until that happens the cluster may form and dissolve again [79]. Nucleation of films is heterogeneous, meaning that it is more likely to happen at some places than others. This is because the surface is not perfectly flat and surface defects, such as kinks and steps, provide energetically favorable sites for nucleation as they reduce the critical size of the nucleus.

In the initial stages of films growth the growth process can be divided into three basic modes: (1) island (or Volmer-Weber), (2) layer-by-layer (or Frank-Van der Merwe), and (3) both island and layer (Stranski-Krastanov). Islands form when the atoms are more strongly bound to each other than the substrates while layer-by-layer growth is observed if they bind most strongly to the substrate than to each other. Layer-by-layer growth is the mechanism in play when films grow epitaxially, i.e. as an extended singlecrystal film on top of the crystalline substrate. In case the film and the substrate is not of the same material epitaxial growth is still possible if the lattice mismatch is small. In some cases the layer-by-layer growth can become unfavorable after the formation of a few monolayers and island growth will take over resulting in the Stranski-Krastanov growth mechanism [58].

Epitaxial relations in the growth of YSZ and CGO on various substrates have been explored in several reports [80-82]. In paper I epitaxial growth is also investigated where YSZ is deposited on NiO-YSZ SOFC anodes. In this case the films are seen to exhibit local epitaxial growth on the individual grains in the substrate but are globally polycrystalline.

The process of growing a polycrystalline film is illustrated in figure 4.1. After forming, the islands grow larger as more adatoms come in contact with them. Eventually, the island density becomes higher when more islands form on the surface as sputtered species continue to arrive. When the islands meet, they start to coalesce as the larger islands grow bigger at the expense of smaller islands. As the smaller islands are consumed open spaces appear on the substrate which allows for further nucleation events. During this coalescence there is also a driving force for coarsening, which means that islands with lower energy per atom consume other islands. As a consequence of 
coarsening, films may exhibit preferential crystalline orientation, even though they are deposited on amorphous or randomly-oriented polycrystalline substrates. The driving force for these processes is the minimization of the overall surface and interface energy of the thin film. Grain coarsening and coalescence continue to occur until the grain size becomes so large that the grain boundaries become immobile $[65,83]$. After this point the film grows in columns.
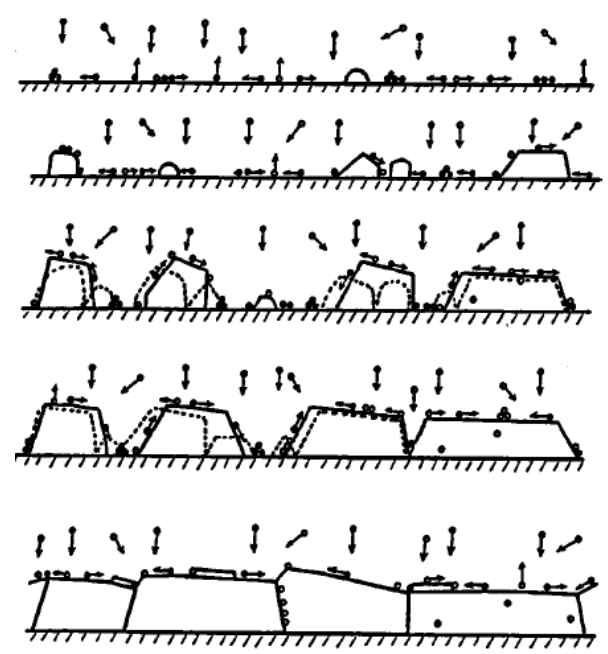

Figure 4.1: Schematic drawing from [65] illustrating the different stages of growth in the formation of a polycrystalline thin film: nucleation, island growth, coalescence of islands and grain coarsening. (๑) American Vacuum Society, reprinted with permission.

\subsection{Controlling the growth of polycrystalline thin films}

When understanding how films grow it is of course also highly interesting to be able to influence and control the growth and tailor the film microstructure to obtain certain properties. In the case of YSZ and CGO coatings for SOFC application the main focus, besides obtaining high ionic conductance, is on growing a dense coating to prevent leaks and diffusion. There are several ways of influencing the film growth but the key idea is to provide energy to the adatoms and the growing film. Depending on the pressure and substrate-target distance, the sputtered flux is typically not thermalized when impinging on the substrate and the adatoms already have some kinetic energy upon arrival. Adatom mobility can be increased by heating the substrate or by the application of substrate bias voltage. As discussed in section 3.4 the application of negative substrate bias voltage draws positive ions to bombard the surface and provide energy to the film. Another way of increasing adatom mobility is by increasing the flux of ionic species that that impinge 
on the substrate and transfer their energy. If some of the sputtered species gets ionized as well these will be bombarding the growing film too. In case a substrate bias voltage is employed these ionized sputtered species can be accelerated to have energies of several electron volts and thereby have larger impact on the film growth. An example is the HiPIMS deposition of $\mathrm{Zr}$ and $\mathrm{Y}$ with $\mathrm{Ar}$ as in papers $\boldsymbol{I I}$ and $\boldsymbol{I I I}$. As discussed in section 3.8, HiPIMS deposition allow for a large degree of control over the ionic flux density and composition.

A general description of the evolution of microstructure when considering the energy provided to the growing film is given by the structure zone models (SZM) $[65,83]$. The SZM divides the film growth into four zones based on the homologous temperature which is the substrate temperature divided by the melting temperature of the deposited material. More complex SZM which takes into account other effects, such as ion bombardment, have also been developed. The Thornton diagram is the most wellknown example [84]. Several adapted versions have been made over the years including an extended one to include energetic deposition methods such as HiPIMS [ 85]. Figure 4.2 shows this version by A. Anders [85]. The temperature, $T^{*}$, is generalized by including a shift caused by potential energy of arriving particles, and the normalized energy, $E^{*}$, includes pressure and kinetic energy of bombarding particles.

In zone 1 the adatom diffusion is negligible and therefore the film is underdense as crystalline fibers grow out of the primary nuclei. The columns are polycrystalline and the film has a random orientation. Zone $\mathrm{T}$ is characterized by an inhomogeneous structure along the film thickness and shaped facets on the top. After initial growth and coalescence, the grain boundaries become immobile and competitive growth starts where surfaces with low potential energy capture more diffusing adatoms than surfaces with high potential energy. As a result, grains with low diffusivity overgrow other grains and a preferred orientation evolves. In zone 2, both bulk diffusion and surface diffusion take place throughout the film thickening process. Therefore, large textured grains evolve driven by a minimization of grain boundary and surface energies. In zone 3 , globular three dimensional grains are formed as both bulk diffusion and recrystallization occurs. In this thesis, the SZM formalism is used to describe the film growth of YSZ in papers I and $\boldsymbol{I I I}$ where the deposited films display structures corresponding to zone T and zone 2. Besides the 4 zones, figure 4.2 also shows how high kinetic energies can result in ion etching or fine-grained structures as the crystal growth is disrupted. The latter is addressed for YSZ in papers $\boldsymbol{I I}$ and $\boldsymbol{I I I}$.

It should be stressed that a number of parameters influence the growth and therefore the SZM only provide an approximate picture of the relationship between growth conditions and structure. For example has it been seen that the addition of dopants can strongly affect the film growth and function as grain refiners [65]. Of the same reason this model is not necessarily applicable to all compound materials. 


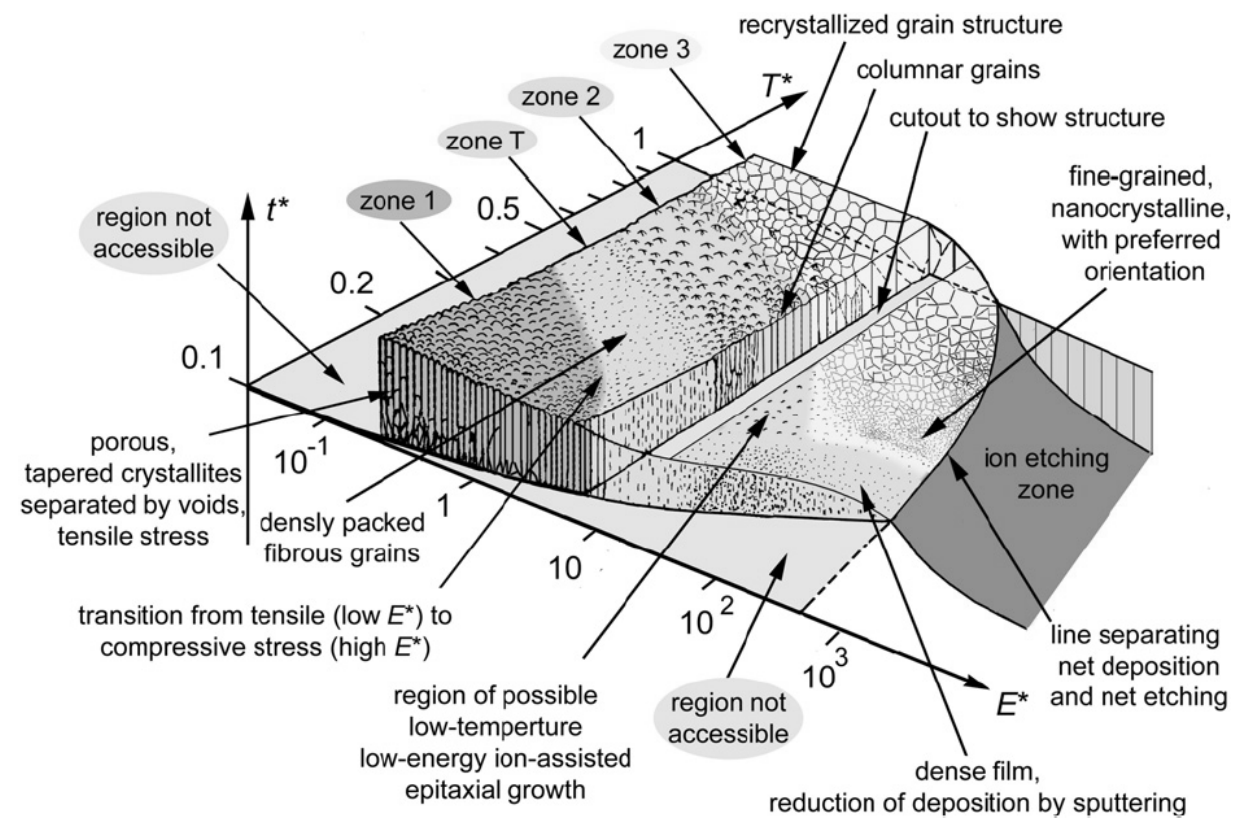

Figure 4.2: Structure zone model for deposition of thin films by A. Anders [85]. This model is applicable for energetic deposition. $E^{*}$ represents normalized energy flux, $T^{*}$ is generalized temperature and $t^{*}$ is net thickness. () Elsevier, reprinted with permission. 


\section{CHARACTERIZATION TECHNIQUES}

This chapter contains brief descriptions of the different methods used in order to characterize the deposited thin films. The choice of analysis method depends on the properties one wishes to investigate, the resources available, the precision needed, and the nature of the materials under investigation. The focus of this chapter is not the physics behind the methods but the kind of information that can be obtained by applying the methods.

\subsection{Structural characterization}

\subsubsection{X-ray diffraction (XRD)}

$\mathrm{XRD}$ is a commonly used analysis technique as it is versatile and can be used for determining a number of microstructural properties of thin films, such as the crystalline phase, film orientation, epitaxial relations, grain size, and lattice strain [86,87]. Atoms in crystals are ordered in a three-dimensional periodic structure within distinct volumes The high degree of order and periodicity in a crystal can be visualized as a stack of crystallographic lattice planes that are all parallel to each other. Planes are described by the Miller indices ( $\mathrm{h} \mathrm{k} \mathrm{1)}$, where the integer $\mathrm{h} \mathrm{k} 1$ triple is related to the points of intersection of the lattice planes with the edges of unit cell.

As X-rays have wavelengths of the order of $1 \AA$, which is comparable to the interatomic spacing in crystals, detection of discrete diffraction patterns is possible. When X-ray radiation interacts with matter, it can be elastically scattered. Scattering on periodic arrays of atoms in crystals results in constructive and destructive interference which gives rise to the diffraction pattern. This phenomenon can be described mathematically by Bragg's law

$$
2 d_{h k l} \sin \theta=n \lambda,
$$

where $d_{h k l}$ is the distance between the hkl-lattice planes, where $h, k, l$, are the Miller indices, $\theta$ the scattering angle, $\lambda$ the wave length of the X-rays, and $n$ is an integer. In addition to meeting the requirements set by Bragg's law, the possibility for constructive interference also depend on the structure factor. The structure factor is inherent to the material and to the electron density of the atoms. During XRD measurements, a range of diffraction angles is scanned and the diffraction intensity is recorded as a function of the angle. The resulting X-ray pattern or diffractogram can be viewed as a "fingerprint" of

\footnotetext{
${ }^{\ddagger}$ This is true for conventional crystals but not quasicrystals which are aperiodic.
} 
the crystal structure and used for identification of the material by comparing with diffraction standards from databases.

\section{$\theta-2 \theta$ scan geometry}

The standard mode of operation is the $\theta-2 \theta$ scan geometry which has been used in papers $\boldsymbol{I}-\boldsymbol{V}$. In this geometry, the angle of the incident beam and the detector are continuously varied, but they make equal angles with respect to the sample throughout the scan. Therefore, only planes parallel to the surface are probed. This geometry is illustrated in figure 5.1.a. Here, $\mathbf{K}_{\mathbf{0}}$ and $\mathbf{K}$ are wave vectors that describe the direction of the incoming and diffracted beam. $\mathbf{Q}$ is the resulting scattering vector which is normal to the diffracted plane and in this case the film surface.

The recorded diffraction pattern is used for determining the crystal phase. For thin films, it is often also interesting to determine the preferred orientation, or texture, of the sample. This is done by comparing the relative intensity of the peaks in the recorded diffractogram to the relative intensities of the peaks in a randomly oriented reference sample from the database. Figure 5.1.b shows a typical x-ray diffractogram. In this case both cubic YSZ and CGO are found and there is no overall texturing.

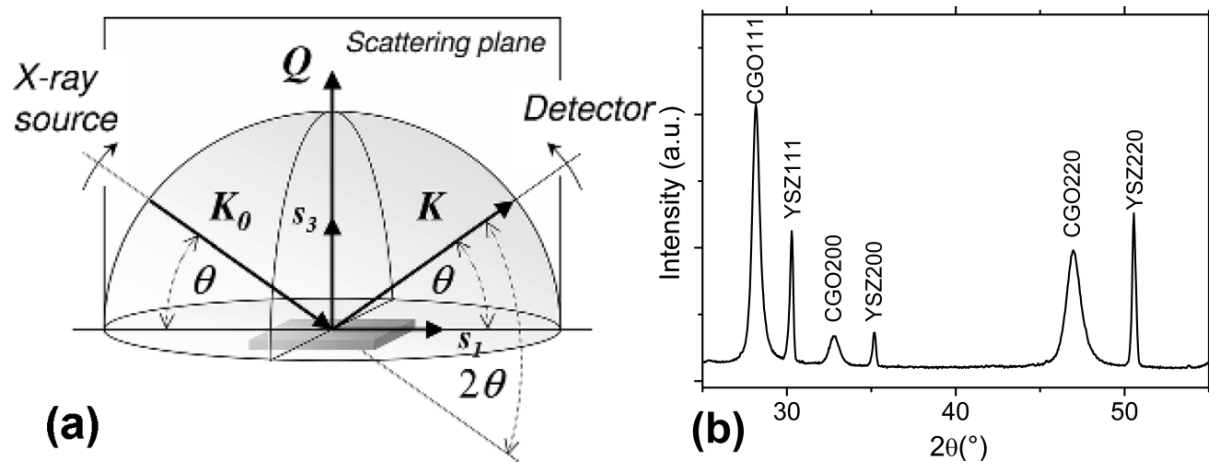

Figure 5.1: (a) Schematic representation of the $\theta-2 \theta$ scan geometry. The incident X-rays with wave vector $K_{0}$ are scattered at the angle $2 \theta$ resulting in the diffracted wave vector $K$. $\mathbf{Q}$ is the scattering vector. Figure from Birkholz [87], () Wiley-VHC Verlag, reprinted with permission. (b) $\theta-2 \theta$ diffractogram recorded for CGO deposited on YSZ.

In addition to yielding information of film phases and preferred orientation the position and shape of the peaks can be used to derive information on the microstructural features of the film. Macrostrain can be detected by observing small shifts in peak position due to changes in lattice distance. For compressive stress, the result is peaks shifting to lower $2 \theta$ angles as the lattice distance of the probed plane is increased. This is seen in papers $\boldsymbol{I}$ and $\boldsymbol{V}$. Peak broadening is related to the grain size of the crystallites 
(coherence volumes) that makes up the sample as well as microstrain induced by the distortions in the crystal structure. Polycrystalline specimens with large and microstrainfree grains display sharp peaks. In figure 5.1.b the difference is obvious between the YSZ substrate and the sputtered CGO film where the CGO film has the smallest and most stressed grains. By analyzing the broadening (full with at half maximum) of the recorded peaks, conclusions on the crystallite size and microstrain can be drawn.

According to theory [88], the shape of the peak profile can be modeled as a convolution of non-microstructural factors and a microstructure-related profile. Furthermore, the microstructure-related profile consists of two contributions related to stain and size broadening. To extract microstructural information from the profile, the single-line analysis method based on a Voigt function introduced by Keijser et al. [89] has been used in this thesis. A Voigt function is a convolution of a Lorentzian and a Gaussian function. In this model the size broadening is described by a Lorentzian function,

$$
L(x)=\frac{1}{\beta_{L}\left[1+\pi^{2}\left(\frac{x}{\beta_{L}}\right)^{2}\right]}
$$

and the strain by a Gaussian function

$$
G(x)=\frac{1}{\beta_{G}} \exp \left(-\pi\left(\frac{x}{\beta_{G}}\right)^{2}\right) .
$$

Here $\beta_{L}$ and $\beta_{G}$ are defined as the ratio of the peak area to the maximum peak intensity. Due to the large computing effort needed to fit the data, a simplified pseudo-Voigt function consisting of a weighted superposition of the Lorentz and Gauss functions are much more used [87]. The values $\beta_{L}$ and $\beta_{G}$ of the Lorentzian and Gaussian constituents of the pseudo-Voigt profile can be found from empirical formulae. The average crystallite size is then given by the Scherrer equation

$$
D_{h k l}=\frac{\lambda}{\beta_{L, h k l} \cos \theta_{h k l}},
$$

and the microstrain is given by the root-mean-square expression

$$
\left\langle\varepsilon^{2}\right\rangle_{h k l}^{\frac{1}{2}}=\frac{\beta_{G, h k l}}{5 \tan \theta_{h k l}} .
$$


It should be noted that the calculated crystallite sizes are the average size of coherently diffracting domains, and not necessarily identical to the actual grain size as defects in in the crystal generally shorten the coherence length. Nevertheless, the calculation can be used as a measure to evaluate the evolution in grain size under different conditions for the deposited films. In this work changes in lattice strain and grain size has been addressed in paper $\boldsymbol{V}$.

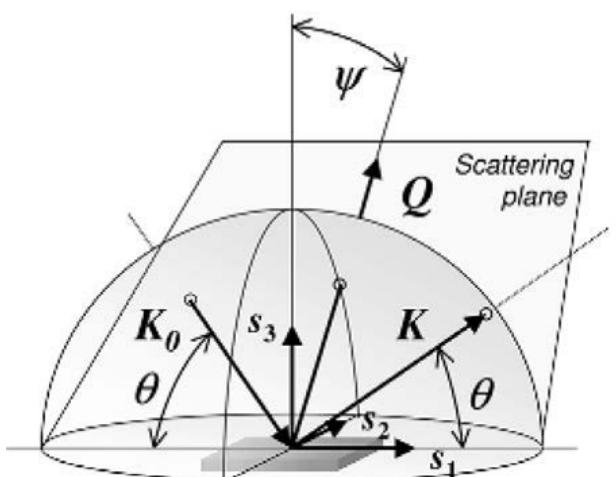

(a)

Sample

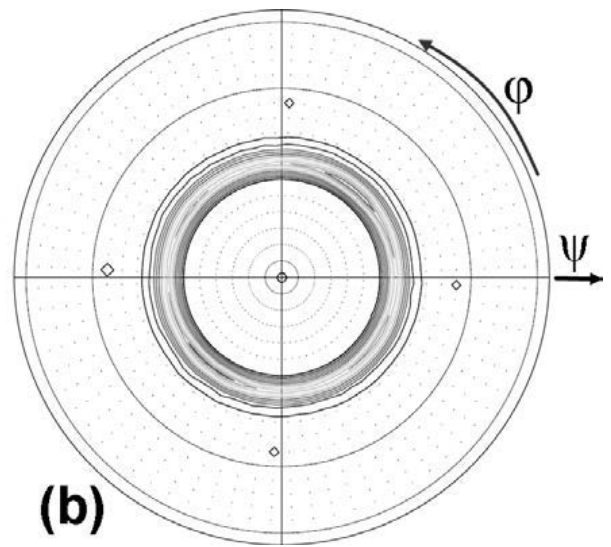

Figure 5.2: (a) Schematic representation of the $\Psi$ tilt in the setup for measurement of pole figures. After performing a scan while rotating the sample around the sample normal, the scattering plane is tilted by the angle $\Psi$. Figure from Birkholz [87], () Wiley-VHC Verlag, reprinted with permission. (b) Pole figure measured at $2 \theta=29.54^{\circ}$ from a cubic YSZ film. A reflection is seen at $\psi=35^{\circ}$.

\section{Pole figure measurement}

Another commonly used approach to determine the preferred orientation or texture of a thin film is to make pole figure measurements. Pole figures can determine texture more completely than $\theta-2 \theta$ scan as it is possible to distinguish between fiber texture, where the in-plane orientation is random but with a preferred out-of-plane orientation, and biaxial texture, where an inherent in-plane mirror symmetry is present. Furthermore, epitaxial relations can be determined. The geometry of the experimental setup for this kind of measurements is shown in figure 5.2.a. The $\theta$ and $2 \theta$ angles (detector position) are kept fixed in order to detect the reflection from a certain plane and then the sample is rotated $360^{\circ}$ around the sample normal (the azimuth angle, $\varphi$ ). When the scan is completed the scattering plane is tilted and a new scan is performed. The tilt angle, $\psi$, is typically a few degrees. After repeating the scan cycles for several tilt angles a stereographic projection of the reflections present can be presented as a pole figure as seen in figure 5.2.b. This pole figure of an YSZ film has been measured at $2 \theta=29.54^{\circ}$, which corresponds to the (111) plane in cubic YSZ. A diffraction ring is seen at a tilt angle of $35^{\circ}$ which is the 
angle between the (111) and (220) planes. Combined with more pole figures measured at $2 \theta$ angles corresponding to other reflections, this figure show the film to be (220) textured. As the diffraction pattern forms a ring there is no in-plane alignment and the film has fiber texture.

\subsubsection{Scanning electron microscopy (SEM)}

The SEM [58, 90] is one of the most widely used instruments for materials characterization as it provides easily understood images of the sample and is simple to use. In the SEM, a beam of electrons, generated by a filament or field emission gun, is accelerated (at a voltage usually in the range of $3-20 \mathrm{keV}$ ), and focused by magnetic lenses onto a point on the sample which is scanned repeatedly. The interaction between the sample surface and the electron beam results in the emission of secondary electrons, backscattered electrons, and X-rays, all of which can be used to gather information about the specimen. The emitted electrons need to be detected and transformed into an electric current to form an image. Secondary electrons are emitted when loosely bound valence electrons in the sample material is excited by collision with the incoming electron beam. Due to the low energy (less than $50 \mathrm{eV}$ ) [91] of the secondary electrons they have the smallest sampling volume and are therefore capable of giving a better spatial resolution than backscattered electrons. The number of ejected secondary electrons depends on the orientation of the scanned surface with respect to the incident electron beam. A surface perpendicular to the incident beam emits fewer secondary electrons than a sloping surface. As a result, detection of secondary electrons gives a high topological contrast. The number of backscattered electrons emitted is proportional to the atomic number of the specimen atoms. Therefore, detection of backscattered electrons results in a compositional contrast. Detection of backscattered electrons has been used for imaging of the CGO films in papers III-VI, in order to distinguish the CGO layer from the YSZ.

A weaknesses of SEM is that if an insulating specimen, such as YSZ or CGO, is examined the beam of electrons will cause an accumulation of negative charge on the specimen. This generates an electrical potential that deflects the electron beam and distort the image. To prevent charging, the specimen can be coated with a thin layer of a conductive material such as gold or carbon. Another option is to use a SEM capable of operation at higher pressure and let in a gas to neutralize the charge build-up. This is possible as the gas gets ionized (positively charged) by the incident beam and electrons emitted from the specimens [91].

The SEM has a maximum resolution of a few nanometers, however the useful magnification of SEM images ranges from a few hundred times to several hundred thousand times depending on the features under investigation. In this work, SEM is used for imaging of sample surfaces and cross-sections in order to study film coverage of the 
substrate, surface topography, and morphology. Micrographs of cross-sections have been used to determine film thicknesses. A SEM capable of injecting water vapor into the chamber and operating at low vacuum was used to acquire micrographs of the insulating YSZ and CGO coatings. Figure of 5.3 shows an example of a cross-sectional SEM image of an YSZ electrolyte coating and CGO barrier coating. Detection of backscattered electrons was used in order to differentiate between the two coatings.

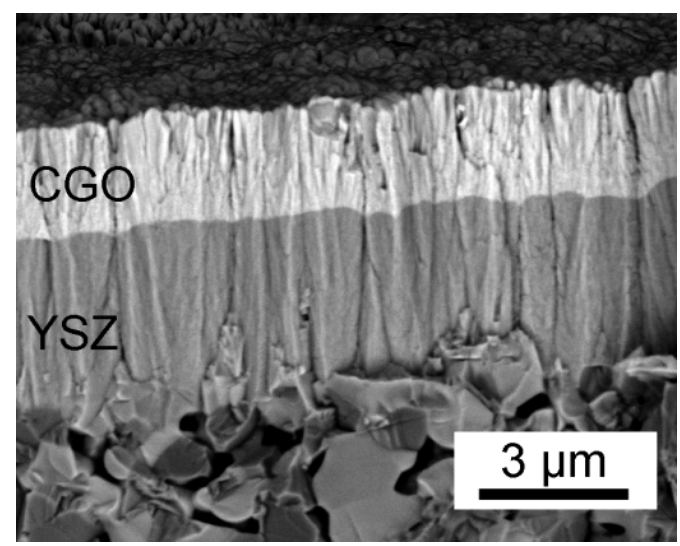

Figure 5.3: Back-scatter SEM cross-section image of YSZ and CGO coatings deposited on NiO-YSZ SOFC anode.

\subsubsection{Transmission electron microscopy (TEM)}

As implied by the name, TEM $[92,93]$ is used to obtain structural information from samples thin enough to transmit electrons. Similar to SEM, a beam of electrons is generated by a filament or field emission gun, accelerated towards the sample, and focused by magnetic lenses onto a point on the sample. However, the energy of the electrons is of the order of $100-400 \mathrm{keV}$, which is much higher than in SEM. The wavelength of electrons are given by the de Broglie relationship

$$
\lambda=\frac{h}{\sqrt{2 m q V}},
$$

where $h$ is Planck's constant, $m$ the electron mass, $q$ the electron charge, and $V$ is the potential drop. Due to the large potential drop, the wavelength of the electrons is in the range of picometers, but because of imperfect lenses the resolution of the TEM is limited to the order of $1 \AA$. This means atomic size resolution is possible with TEM. To achieve high quality data from the TEM, the sample needs to be thinned to approximately $50 \mathrm{~nm}$ 
in order to reduce multiple scattering when electrons transverse through the sample. Such thin samples are typically prepared by mechanical grinding and polishing followed by ion etching. This procedure is time-consuming, requires skill, and in modern TEM it is the main limitation on the resolution that can be achieved.

When electrons pass through the sample they can be transmitted or scattered. By applying different objective apertures, different modes of imaging are possible. Brightfield images are obtained by intentionally excluding all diffracted beams and only allowing the central beam through the objective aperture. In this mode, contrast is formed by diffraction and mass thickness. Therefore crystalline areas and thicker samples will appear dark. Dark-field images can be formed by blocking out the central beam which gives the inverse contrast of bright-field imaging. Instead of using an aperture for imaging, one can record the electron diffraction pattern. Selected area electron diffraction (SAED) makes it possible to probe only a desired area and obtain information about the crystal structure, lattice spacing, and orientation.

Figure 5.4 shows a bright field micrograph of the cross-section of a YSZ film and SAED of the film-substrate interface. The SAED shows that the film and substrate has the same orientation. This example is from paper $I$ where SAED was used to study any epitaxial relationship between YSZ films and NiO-YSZ SOFC anodes while the TEM micrograph was used to study the microstructure of the films.

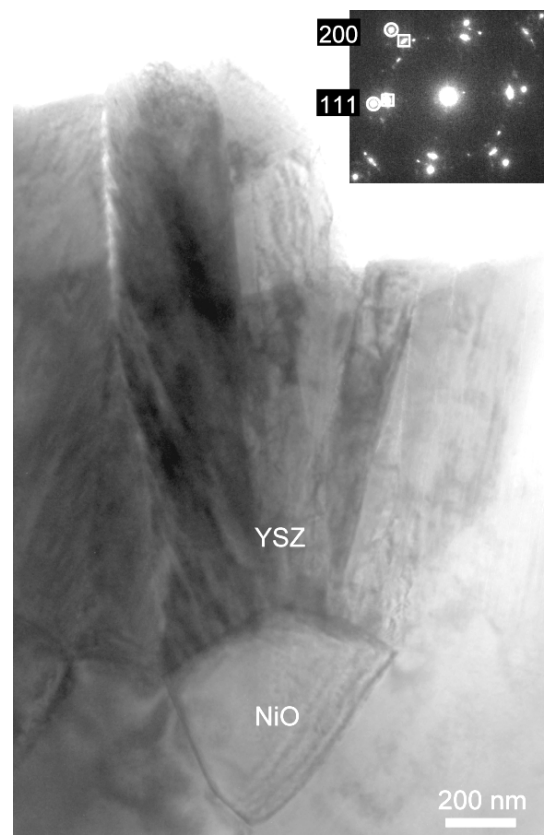

Figure 5.4: TEM cross-section image of YSZ on a NiO grain in a SOFC NiO-YSZ anode. SAED is performed at the film-substrate interfase to show that the film and substrate have the same orientation. Figure adapted from paper I, () Elsevier, reprinted with permission. 
Scanning TEM (STEM) is a mode of operation where the electron beam is condensed to a spot size of $\sim 1 \mathrm{~nm}$ and scanned across the sample, as in the SEM. The transmitted signal is then collected as a function of beam location, typically by a highangle annular dark field (HAADF) detector. The contrast is mass- and thicknessdependent. It is possible to combine STEM mode with other techniques, typically energy dispersive $\mathrm{x}$-ray spectroscopy (EDX) or electron energy loss spectroscopy. In this thesis, STEM has been combined with EDX to map the elemental concentrations in the samples as seen in papers $\boldsymbol{I} \boldsymbol{V}$ and $\boldsymbol{V}$ in order to study the diffusion of $\mathrm{Sr}$ through sputtered CGO layers.

\subsection{Compositional analysis techniques}

\subsubsection{Energy dispersive X-ray spectroscopy (EDX or EDS)}

EDX [94] is an analytical method for probing the chemical composition, often integrated in SEM and TEM equipment. When the accelerated beam of electrons used for probing in SEM/TEM interacts with the sample, electrons from an inner shell of a sample atom may be ejected. An electron from and outer shell will fill the hole and emit X-rays in the process. As the energy of the X-ray depends on the electronic structure of the atom, identification and quantification of the elements in the sample is possible. EDX is best suited for quantification of "heavy" elements $(Z>10)$. Quantification of light elements is less precise due to low X-ray yields and low energy of the X-rays. H, He, and Li cannot be detected. Therefore, this technique is well supplemented with other techniques for determination of chemical composition, such as Elastic Recoil Detection Analysis (ERDA), which is most sensitive for light elements. This has been done in paper $I$ for composition analysis of the deposited YSZ thin films.

When performing EDX measurements, one can choose either to make a rapid determination of the elements present in the sample. Alternatively, one can obtain information on the distribution of elements by performing a more time consuming mapping of the area of interest. STEM combined with EDX mapping was performed in papers $\boldsymbol{I V}$ and $\boldsymbol{V}$ in order to study $\mathrm{Sr}$ enrichment in CGO thin films due to diffusion. By combining STEM with EDX it is possible to map the elemental distribution at the nanometer scale whereas EDX mappings in SEM have a resolution in the micrometer scale due to a much larger sampling volume. Figure 5.5 shows an example of an STEM EDX mapping of $\mathrm{Sr}$ in a fuel cell setup from paper $\boldsymbol{I} \boldsymbol{V}$. The $\mathrm{Sr}$ is seen to diffuse from the LSCF cathode to the CGO-YSZ interface along channels which in paper $\boldsymbol{I V}$ are shown to be grain/column boundaries. This could not be resolved by EDX in SEM. 

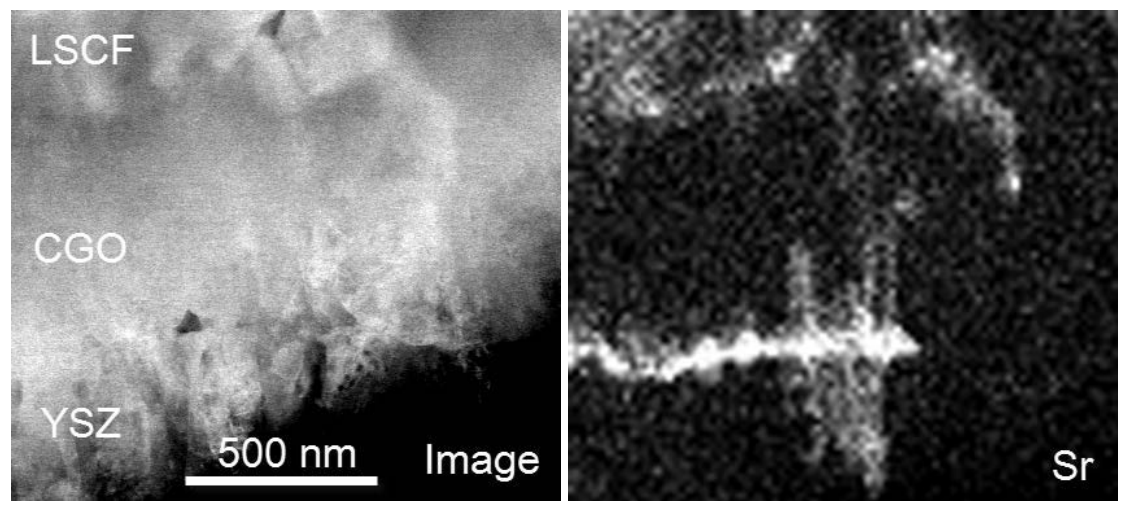

Figure 5.5: STEM cross-section and EDX mapping of Sr distribution in the sample. Figure adapted from paper IV, () Wiley-VHC Verlag, reprinted with permission.

\subsubsection{Ion-beam analysis}

\section{Elastic recoil detection analysis}

Elastic recoil detection analysis (ERDA) [95] is an ion-beam analysis technique used to determine the elemental composition of the thin films. In this technique, the sample is irradiated by a beam of heavy ions such as chlorine, iodine, or gold accelerated to energies of several $\mathrm{MeV}$ by a tandem accelerator. Heavy ions are used in order to transfer enough energy to the sample and knock out atoms from the film. In this work, a beam of $40 \mathrm{MeV}^{127} \mathrm{I}^{9+}$ has been used. The angle of incidence is lower than $90^{\circ}$ resulting in target atoms being knocked out and recoiled in the forward direction. The principle is shown in figure 5.6. A detector is positioned at the exit angle and receives a mix of scattered projectiles and recoiled targets atoms that arrive with overlapping energies. A time offlight energy (ToF-E) detector which measures both the velocity and the particle energies is used. As the kinetic energy of the particle is given by

$$
E=\frac{1}{2} m v^{2}
$$

where $m$ is the mass and $v$ the velocity, it is possible to resolve both for energy and mass and thereby distinguish the different particles. The information obtained by ERDA is a combination of mass, composition, and depth profiling. ERDA has a high sensitivity for light elements such as $\mathrm{C}, \mathrm{O}$ and $\mathrm{H}$ but cannot distinguish between heavier elements with almost the same mass, such as $\mathrm{Y}$ and $\mathrm{Zr}$ which are neighbors in the periodic table. In this work, ToF-E ERDA has been used in paper $\boldsymbol{I}$ to determine film composition in combination with EDX which is not accurate for light elements but can separate $\mathrm{Zr}$ from $\mathrm{Y}$. 


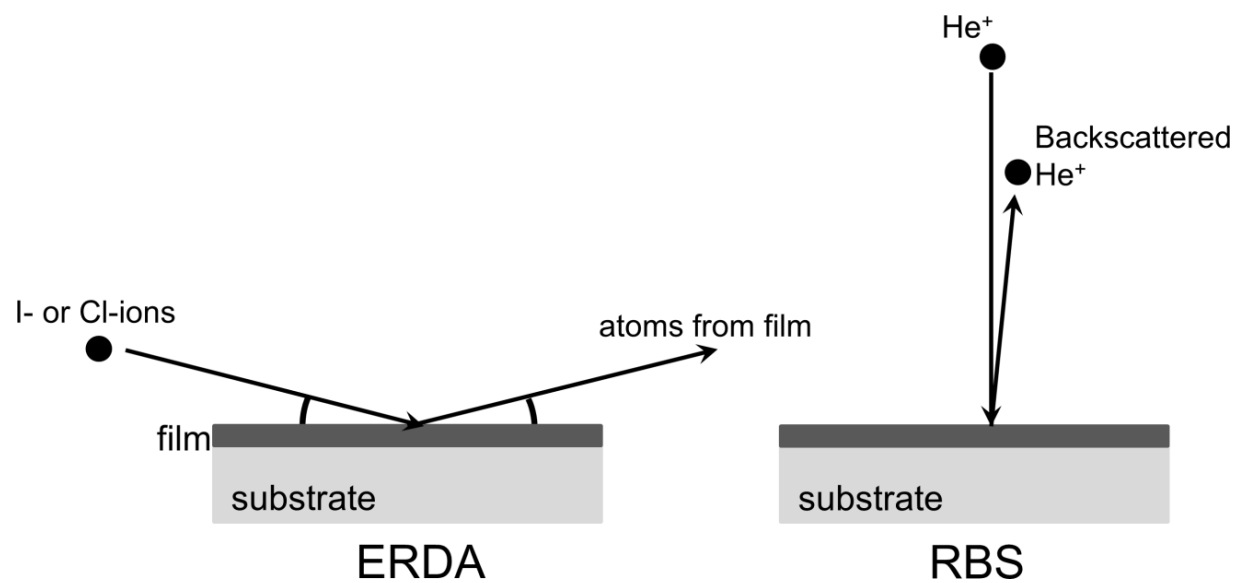

Figure 5.6: Schematic drawings of the principle of ERDA and RBS. In ERDA heavy ions knock out sample atoms which are recoiled in a forward direction. In RBS light ions are backscattered when hitting the sample.

\section{Rutherford Backscattering Spectrometry}

Rutherford Backscattering Spectrometry (RBS) [96,97] is another ion-beam technique closely related to ERDA. In RBS, a high-energy ion beam with low-mass ions, typically $\mathrm{He}^{+}$, is directed at the sample at a normal incidence angle. Some ions will get implanted in the sample while other will collide with atoms in the sample and be scattered backwards. At a certain angle a detector is placed which record the energy of the backscattered particles. The ratio between the energy of the ion before and after collision is called the kinematic factor and depends on the mass of the ion, the mass of the element it collided with, and the angle of scattering. Therefore, one can determine the elemental composition of the sample by measuring the energy of the backscattered particles at a known angle. If the incident ion traverses the sample before and after being backscattered it will undergo several inelastic collisions before leaving the sample. As a result it will arrive at the detector at a lower energy than ions backscattered at the surface. The information obtained by RBS is therefore a composition and depth profile of the sample. Figure 5.7 shows a typical RBS spectrum. The "channel number" corresponds to the energy of the backscattered particles with a higher number meaning higher energy. Each feature in the spectrum corresponds to an element and the width of the feature to the thickness of the layer. Software such as SIMNRA [98] can be used to simulate the spectrum and determine the composition. Like ERDA, RBS cannot distinguish between heavy element neighbors such as $\mathrm{Y}$ and $\mathrm{Zr}$. This can be seen in figure 5.7 where the signal for $\mathrm{Y}$ and $\mathrm{Zr}$ completely overlap. Furthermore, detection of light elements is inaccurate due to low backscattering yield. However, in the YSZ and CGO coatings 
presented here a reasonable estimate of the oxygen content can obtained as oxygen is a main constituent of the films. RBS has been used in paper II together with EDX to determine the composition of YSZ films.

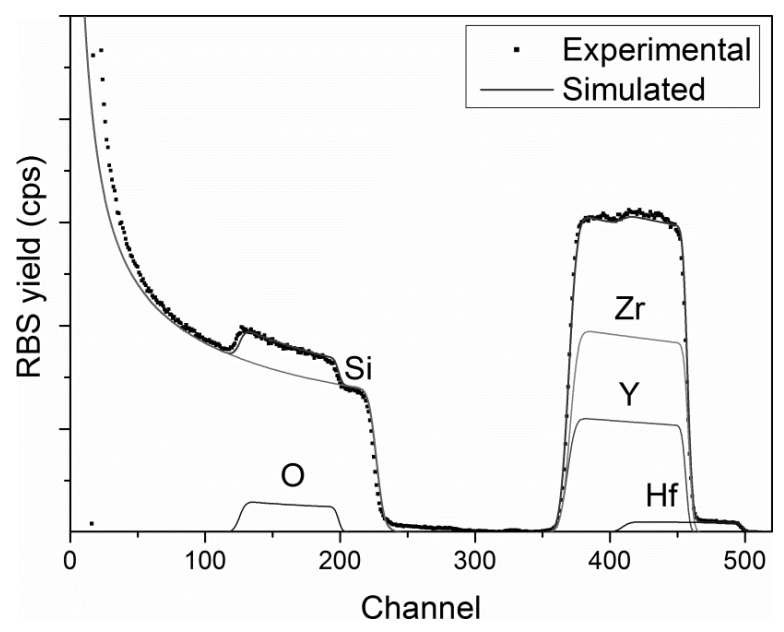

Figure 5.7: RBS data measured for an YSZ sample deposited on Si using a $2 \mathrm{MeV} \mathrm{He}^{+}$ beam. The experimental data as well as the curve simulated to calculate the composition are shown. 


\section{CELL TESTING}

In this section, a short introduction is given to the cell testing [99] performed in papers $\boldsymbol{V}$ and $\boldsymbol{V I}$ in order to assess the performance of fuel cells.

No general agreement on test procedures exists, which often makes it difficult to compare reported results. Therefore, a precise description of the applied test procedure must be given when presenting data. Extensive cell testing is usually only carried out on single cells or cell components. Full stack tests, which incorporate multiple cells and system components, are expensive and the results can be difficult to analyze. However, stack tests are conducted to assess the commercial viability of a setup.

In this work, fully assembled cells consisting of anode, electrolyte, and cathode have been tested in a single cell setup. A typical setup for testing of planar SOFCs is to place the cell in a test house sandwiched between gas distribution plates. The edges of the cell are effectively sealed in the test house by a glass seal to prevent gas leaking. On each side of the cell Pt or Au foils are placed to pick up the electrode current. The test house has built-in inlets and outlets for fuel and air as well current collectors, voltage probes, and thermocouples for measuring the temperature. The whole assembly is heated in a furnace to achieve the desired testing temperature before testing is started.

\subsection{Polarization curves}

Often the results of cell tests are reported in the form of power density. However, the power output is highly dependent on fuel composition and cell voltage and can therefore be a confusing measure. A better method to characterize the performance of SOFCs is to examine current density-voltage $(\mathrm{i}-\mathrm{V})$ polarization curves. As seen in figure 6.1 , the $\mathrm{i}-\mathrm{V}$ curves for SOFCs are approximately linear, which allows the use of area-specific resistance (ASR) as an appropriate measure of performance. Largely, the ASR value is only sensitive to the temperature and is defined as

$$
A S R=\frac{E M F-U}{i}
$$

where $E M F$ is the electromotive force, and $U$ is the cell voltage at the current density, $i$, at the design point for the measurement.

Polarization curves and ASR values are measured in papers $\boldsymbol{V}$ and $\boldsymbol{V I}$ on cells containing sputtered CGO barrier coatings. 


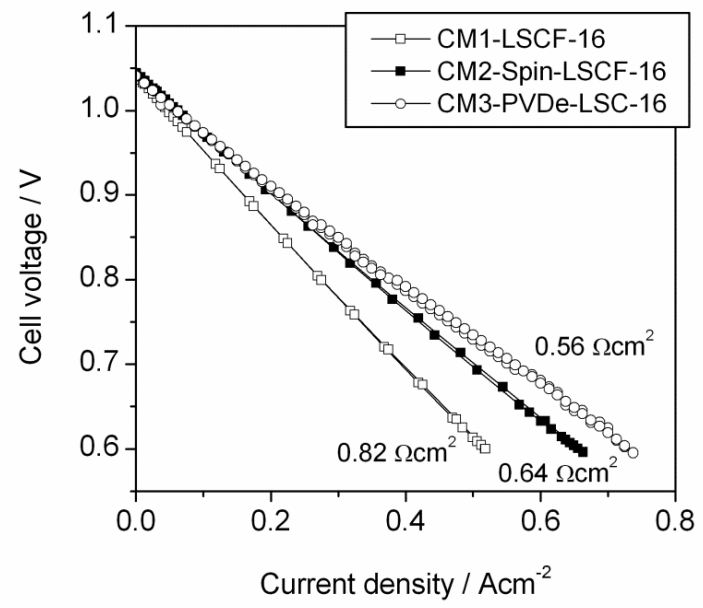

Figure 6.1: Polarization curves from cell testing of three different cells. ASR values are given next to the curves. Figure from paper VI, @ Elsevier, reprinted with permission.

\subsection{Electrochemical impedance spectroscopy (EIS)}

EIS is a powerful technique for the characterization of electrochemical systems as it has the ability to distinguish between influences from different processes, such as reaction/migration steps $[25,100]$. The experimental procedure involves subjecting the cell to a small $\mathrm{AC}$ excitation voltage $(<1 \mathrm{~V})$ of frequencies ranging from a few millihertz to several hundred kilohertz and measuring the current response. The overall current response is linear with the same frequency as the applied voltage, but shifted in phase. Because each migration step or reaction, ideally, has a unique time constant associated with it, these processes will respond to signals at different frequencies. Hence, the distribution of the relaxation times enabled one to separate the different loss contributions in the cell by measuring the impedance over a range of frequencies.

The impedance is a complex number given by

$$
Z(\omega)=\frac{U_{0}}{I_{0}} \exp (i \varphi)
$$

where $\omega$ is the angular frequency, $\varphi$ is the phase difference between the voltage and the current and $U_{O}$ and $I_{O}$ are the amplitudes of the voltage and current, respectively. If a DC voltage was used instead of AC, equation 6.2 would be reduced to Ohm's law. 
By use of the Euler relation the impedance can be split into a real, $Z^{\prime}$, and a complex, $Z^{\prime \prime}$, part and written as

$$
Z(\omega)=Z^{\prime}(\omega)+i Z^{\prime \prime}(\omega)
$$

Impedance spectra can be presented by plotting the negative imaginary part of the impedance as a function of the real part (a Nyquist plot) or as a function of frequency (a Bode plot). Both representations are shown in figure 6.2. As the two representations depict different details, both are usually shown. In the Nyquist plot, each data point depicts the impedance at a specific frequency with the frequency increasing from right to left. In this representation, a cell process is seen as a semicircle. In fuel cells, where various processes occur, the response will be a superposition of a number of semicircles. A weakness of the Nyquist plot is that it is not clear how the impedance depends on the frequency. As the Bode representation plots frequency dependency, it supplements the Nyquist representation well. In this work, the Bode plot is combined with analysis of differences in impedance spectra (ADIS). ADIS is a way to visualize differences between two spectra by looking at the differences between the real part derivatives of the two Bode plots [101].

Impedance spectroscopy is used in paper $\boldsymbol{V}$ to find responses that may explain differences in measured ASR values, such as $\mathrm{SrZrO}_{3}$ formation in the cathode-electrolyte interface.
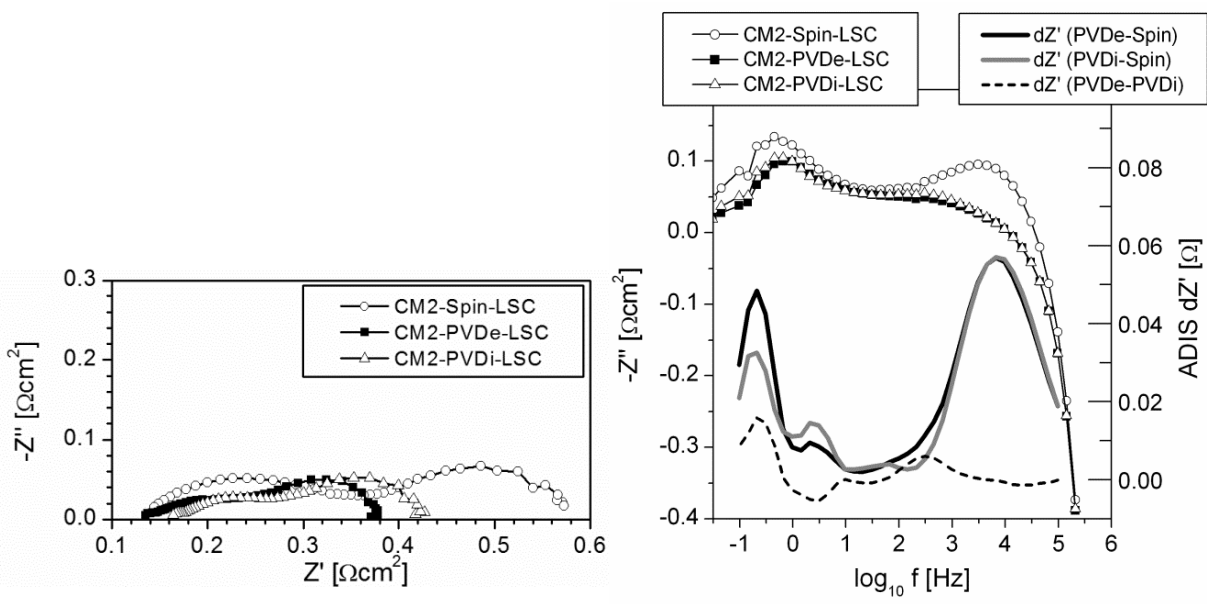

Figure 6.2: Left: Nyquist representation of impedance spectra from three different cells. Right: Combined Bode and ADIS representation of the impedance spectra. Figures from paper VI, () Elsevier, reprinted with permission. 


\section{SUMMARY OF THE APPENDED PAPERS AND CONTRIBUTION TO THE FIELD}

In this thesis, I have explored film growth and microstructure of YSZ and CGO with focus on achieving coatings that are industrially applicable for SOFCs. The presented research covers up-scaling to enable industrialization, investigations and comparisons of depositing by pulsed DC magnetron sputtering and HiPIMS, fundamental studies of $\mathrm{Sr}$ diffusion in sputtered CGO, and cell tests. This chapter gives a summary of the papers included in this thesis and a discussion of how the presented work contributes to the field.

\subsection{Deposition of YSZ}

\subsubsection{Industrial-scale YSZ deposition}

Previous investigations have demonstrated laboratory-scale deposition of YSZ thin films by magnetron sputtering [20,21,102-105]. For industrial applications, it is important to address the deposition time and throughput to keep the cost low enough to be competitive. At the same time, the quality of the deposited coatings needs to be reproducible and uniform throughout the coating area of the entire production unit. When up-scaling from laboratory-scale to industrial-scale, these requirements pose a challenge. This is particularly true when depositing oxides by reactive sputtering which is known to cause a hysteresis effect, non-uniformity of the films, and poor reproducibility [67].

In Papers $\boldsymbol{I}$ and $\boldsymbol{I I I}$, I address these challenges by depositing YSZ films in an industrial setup while having in mind these requirements for industrial applications. Paper I deals with reactive pulsed DC magnetron sputtering of YSZ films and investigation of the texture, morphology, and composition of the deposited films. When depositing on $\mathrm{Si}(001)$ the texture of the films can be tuned by controlling the applied bias voltage. This kind of control is not possible when deposing on NiO-YSZ substrates. Here, TEM investigations of the deposited films show that low bias $(-30 \mathrm{~V})$ caused randomly oriented films. At higher bias, a pronounced template effect is observed which result in films having the same orientation as the underlying substrate. Therefore, these films cannot have any overall texture as the substrate consists of $\mathrm{NiO}$ and YSZ grains with random orientation. In general, the deposited films are prone to form a columnar microstructure which is unfavorable, as it may lead to internal leakage in the cell and decreased open cell potential [103-105]. By increasing the substrate bias voltage columnar film growth can be prevented when deposing on $\mathrm{Si}(001)$ but films deposited on NiO-YSZ substrates are columnar both at high and low bias voltage, however, the size of the columns are dependent on substrate bias. At high bias voltage, the columns are up to 
ten times wider than observed at floating potential which resulted in denser, but nevertheless columnar films. These results show the importance of developing coatings on the same type of substrates as intended for the end application.

ERDA and EDX measurements of samples placed throughout the coating zone during depositions are used to show homogenous YSZ coatings can be deposited over large areas within the coating zone of the sputtering unit. This is important for industrial applications as the prospect of producing uniform coatings across large surface areas is a requirement for the application of sputtered thin film electrolytes.

In paper III industrial-scale deposition was also investigated. Here the deposition technique is changed from pulsed DC magnetron sputtering to HiPIMS in order to achieve denser films. This is further discussed in the next section.

\subsubsection{HiPIMS deposition of YSZ}

HiPIMS deposition has been shown to suppress columnar microstructure and result in dense films, even at low temperatures [73]. As this is the type of microstructure desired for thin film SOFC electrolytes it is of interest to investigate HiPIMS for the synthesis of dense YSZ films. This is the theme of papers $\boldsymbol{I I}$ and $\boldsymbol{I I I}$.

In paper II, laboratory-scale deposition of YSZ by pulsed DC magnetron sputtering and HiPIMS is carried out on SOFC NiO-YSZ anodes and Si under the influence of substrate bias voltage. The difference in the degree of ionization and composition of the ionized flux between the two techniques has significant influence as seen when comparing morphology and texture of the prepared film. When depositing by pulsed DC magnetron sputtering the use of substrate bias increases texturing and results in highly textured films at high bias (-75 V). In contrast, HiPIMS deposited films are crystalline and highly textured at low bias $(-25 \mathrm{~V})$, whereas the intense ion bombardment at high bias voltage disrupt crystal growth and results in reduced grain sizes and less ordered films. The effect of the intense ion bombardment under HiPIMS conditions is also apparent when comparing film morphology. Films deposited by pulsed DC magnetron sputtering are all columnar regardless of the application of substrate bias. HiPIMS films deposited at floating potential are also columnar and contains voids. By applying $-75 \mathrm{~V}$ bias the HiPIMS film obtains a homogeneous and fine grained microstructure but delaminates due to the build-up of stress. At an intermediate bias voltage $(-25$ to $-50 \mathrm{~V})$ a window of operation is found in which it is possible to deposit non-columnar thin films without voids and cracks that may be suitable for SOFC application.

Paper II shows that HiPIMS is a technique that may well be suited for SOFC electrolyte fabrication. Paper III explores HiPIMS further by going from laboratoryscale to industrial-scale. In Paper III, YSZ films are deposited by HiPIMS while taking 
into account industrial parameters such as cycle time and process stability but still maintaining the aim of preparing dense coatings. In order to achieve this goal, cathode peak power density, deposition pressure, and substrate bias voltage are tuned.

Choosing a too low deposition pressure is shown to both result in decreased deposition rate and a more open film structure due to fewer ions for sputtering and for bombarding the film. The peak power density influences the degree of ionization of the sputtered flux. By increasing peak power density the degree of ionization increases which result in increased energetic bombardment of the growing film and hence increased adatom mobility and denser films. However, the deposition rate is significantly reduced when the peak power density is increased. By combining an intermediate peak power density $\left(\sim 0.6 \mathrm{~kW} / \mathrm{cm}^{2}\right)$ with a high substrate bias voltage $(-180 \mathrm{~V})$ a homogeneous and essentially columnless coating can be deposited. This result shows HiPIMS may be suitable from an industrial point of view for YSZ electrolyte deposition.

\subsection{Deposition of CGO}

\subsubsection{Strontium diffusion through sputtered CGO barriers}

In addition to the electrolyte, having an efficient cathode is highly important for the performance of the SOFC [106]. However, to apply novel cathodes such as LSCF and LSC, a CGO barrier is needed between the cathode and the YSZ electrolyte. In order to prepare effective sputtered CGO barriers, it is of great interest to understand the $\mathrm{Sr}$ diffusion mechanism so that the microstructure of the barrier layer can be tailored in such a way that $\mathrm{Sr}$ diffusion may be prevented.

In paper IV, I study the diffusion mechanism of $\mathrm{Sr}$ and the formation of $\mathrm{SrZrO}_{3}$. Furthermore, I investigate the influence of film thickness and applied substrate bias voltage on the effectiveness of reactively sputtered CGO barrier coatings at different temperatures. To do so, a model system consisting of a base layer of sintered LSCF/CGO composite cathode material, a sputter deposited CGO barrier, and a thin top layer of YSZ is set up to simulate a fuel cell. This setup makes it possible to follow $\mathrm{Sr}$ diffusion by observing the appearance of a $\mathrm{SrZrO}_{3}$ peak by in-situ XRD.

It is found that $0.6 \mu \mathrm{m}$ and $1.2 \mu \mathrm{m}$ thick CGO barriers break at $900{ }^{\circ} \mathrm{C}$ and $950{ }^{\circ} \mathrm{C}$, respectively. TEM/EDX shows the diffusion to take place along grain/column boundaries. The observed elongated shape of the $\mathrm{SrZrO}_{3}$ precipitates is attributed to a high driving force for $\mathrm{SrZrO}_{3}$ formation and a limited $\mathrm{Zr}$ diffusion to the reaction zone. The $\mathrm{SrZrO}_{3}$ only forms above LSCF grain in the LSCF-CGO composite and does not spread out sufficiently along the YSZ-CGO interface to form a fully covering layer, leaving patches open for conduction of ions. By depositing at higher substrate voltage denser films can be produced which are able to withstand higher temperatures before $\mathrm{Sr}$ 
diffusion is observed. This observation supports the finding of column boundaries as the major diffusion route. In paper $\boldsymbol{V}$ CGO barriers are implemented in metal-based SOFCs and after cell test cross-sectional TEM samples are prepared from the cell. STEM/EDX investigations confirm the $\mathrm{Sr}$ diffusion along boundaries as observed in the model system in paper $\boldsymbol{I V}$. These results are of scientific and technical importance for the advancement of the SOFC technology as they present a potential route for preventing $\mathrm{Sr}$ diffusion.

\subsubsection{Implementation of sputtered CGO barriers in metal supported SOFCs}

Earlier studies have shown that sputtering is an efficient way to apply CGO barrier coatings to ceramic-based SOFCs due to the high density of the sputtered films $[23,46]$. In papers $\boldsymbol{V}$ and $\boldsymbol{V I}$ we expand these studies by addressing deposition and testing of CGO barriers on metal-based cells. Paper $\boldsymbol{V}$ deals with the optimization of the sputtering process while the electrochemical performance of cells containing sputter deposited CGO coatings are tested against LSC and LSCF cathodes and compared to spin-coated CGO barriers in paper $\boldsymbol{V I}$.

In paper $\boldsymbol{V}$, the influence of bias voltage, deposition temperature and CGO layer thickness is studied in order to optimize the electrochemical performance of the cells. By applying substrate heating or bias voltage the film density is increased. ASR values measured in cell tests decreases as the column boundaries become denser in accordance with the results showed in paper $\boldsymbol{I} \boldsymbol{V}$. Besides densifying the films, bias voltage also results in smaller grain sizes and induces microstrain and compressive stress in the film which have been described in literature to influence cell performance [107]. However, heat treatment of the samples are seen to cause stress release, grain coarsening and reduction of defects (microstrain) which make the microstructure of the films comparable meaning that the effect of these as-deposited film differences are reduced after cathode sintering. Studies of the film thickness show that $0.6 \mu \mathrm{m}$ CGO effectively block $\mathrm{Sr}$ diffusion when depositions are carried out at $400{ }^{\circ} \mathrm{C}$ with the application of bias. This is verified by cell testing where an ASR value of $0.34 \Omega \mathrm{cm}^{2}$ is achieved at $650{ }^{\circ} \mathrm{C}$ with a LSC cathode.

In paper VI, the electrochemical performance of cells containing sputterdeposited or spin-coated CGO barriers with LSCF or LSC cathodes is compared. Whereas the microstructure of the sputtered films is found to be homogenous, the spincoated barrier was both uneven in thickness, discontinuous, and porous. Cell testing shows that for cells with sputter-deposited CGO barriers and LSC cathodes, it is possible to achieve ASR values down to $0.27 \Omega \mathrm{cm}^{2}$ at $650{ }^{\circ} \mathrm{C}$ while the cell with the spin-coated barrier has an ASR value of $0.50 \Omega \mathrm{cm}^{2}$. Impedance data indicates that the less dense spin-coated CGO layer fails due $\mathrm{Sr}$ diffusion and $\mathrm{SrZrO}_{3}$ formation which is not the case for the sputtered barrier. 
The results shown in Papers $\boldsymbol{V}$ and $\boldsymbol{V I}$ prove that application of sputtered CGO coatings in metal-based SOFCs yields cells with high electrochemical performance and display a significant improvement compared to standard ceramic cells with the LSM cathode which have ASR values of $\sim 0.5 \Omega \mathrm{cm}^{2}$ at $750{ }^{\circ} \mathrm{C}$. 


\section{ADDITIONAL RESULTS}

\section{Commercialization of CGO coatings}

In the work presented in papers $\boldsymbol{I V}-\boldsymbol{V I}$, I have studied the microstructure of sputtered CGO coatings and their ability to prevent $\mathrm{Sr}$ diffusion and I have shown successful application of CGO barriers in SOFCs. However, to be interesting from a commercial point of view, film deposition needs to be relatively fast and at the same time be reproducible and able to cover large areas with homogeneous coatings as discussed in paper I. During my work, I have been able to gradually improve deposition rate, reproducibility and film performance by making use of the knowledge gained from the research presented in the papers. This iterative process has gradually resulted in optimized coatings. As a direct outcome of my $\mathrm{PhD}$ work, a CGO coating is now commercially available from the Tribology Centre, Danish Technological Institute. This coating is prepared in the commercial batch coating units from CemeCon AG described in section 3.10. The coating unit can coat fuel cells with an active area up to $21 \times 40 \mathrm{~cm}^{2}$ but typically $13 \times 13 \mathrm{~cm}^{2}$ cells are coated. The developed coating consists of $\mathrm{Ce}_{0.9} \mathrm{Gd}_{0.1} \mathrm{O}_{2-\delta}$ and is deposited at $\sim 400{ }^{\circ} \mathrm{C}$ to obtain the density needed to stop $\mathrm{Sr}$ diffusion as discussed in paper $\boldsymbol{V}$.

Cell testing has been carried out with commercial anode-supported ceramic fuel cells with Ni/YSZ anodes and YSZ electrolytes. The deposited CGO barrier was tested against LSCF and LSC cathodes. In these cases initial ASR values of $0.31 \Omega \mathrm{cm}^{2}$ and $0.16 \Omega \mathrm{cm}^{2}$ have been measured at $750{ }^{\circ} \mathrm{C}$ and $700{ }^{\circ} \mathrm{C}$ for the LSCF and LSC cathodes, respectively. These ASR values are considered to be low for the given setup and show the CGO coating is effective in preventing Sr diffusion for both types of cathodes. Results from long-term durability testing are not available at the moment. As the coating has several similarities to the best coatings presented in paper $\boldsymbol{V I}$ it is also suitable for metal-supported SOFC where the application of CGO barriers is seen to more than halve the ASR from $0.56 \Omega \mathrm{cm}^{2}$ to $0.27 \Omega \mathrm{cm}^{2}$ at $650{ }^{\circ} \mathrm{C}$. A product data sheet for the coating can be downloaded from the Tribology Centre's home page [108].

My contribution to the development process has been to study film deposition and microstructures of the CGO coating while Topsøe Fuel Cell and Risø have delivered cell components and performed cell testing. The project has truly been a close and integrated collaboration between academia and industry, which illustrates the philosophy of industrial $\mathrm{PhD}$ studies, application-inspired fundamental research with immediate relevance in actual products and commercial processes. 


\section{REFERENCES}

[1] R. F. Bunshah, in : R. F. Bunshah (Eds.), Handbook of Deposition Technologies for Films and Coatings, $2^{\text {nd }}$ ed., Noyes Publications, New Jersey, USA (1994), chapter 1.

[2] W. R. Grove, Philosophical Transactions of the Royal Society of London 142 (1852) $87-101$.

[3] 2010 Survey of Energy Resource: Executive Summary, World Energy Council, London, UK (2010).

[4] R. M. Ormerod, Chemical Society Reviews 32 (2003) 17-28.

[5] M.A. Laguna-Bercero, Journal of Power sources 203 (2012) 4-16.

[6] W. R. Grove, Philosophical Transactions of the Royal Society of London 133 (1843) 91-112.

[7] A. B. Stambouli, Renewable and Sustainable Energy Reviews 15 (2011) 4507-4520.

[8] J. M. Andújar, F. Segura, Renewable and Sustainable Energy Reviews 13 (2009) 2309-2322.

[9] A. Choudhury, H.Chandra, A.Arora, Renewable and Sustainable Energy Reviews 20 (2013) 430-442.

[10]N. H. Menzler, F. Tietz, S. Uhlenbruck, H. P. Buchkremer, D. Stöver, Journal of Materials Science 45 (2010) 3109-3135.

[11] T. W. Kueper, S. J. Visco, L. C. De Jonghe, Solid State Ionics 52 (1992) 251-259.

[12] B. C. H. Steele, A. Heinzel, Nature 414 (2001) 345-352.

[13] S. J. Litzelman, J.L. Hertz, W. Jung, H. L. Tuller, Fuel Cells 08 (2008) 294-302.

[14] T. Van Gestel, D. Sebold, H. P. Buchkremer, D. Stöver, Journal of the European Ceramic Society 32 (2012) 9-26.

[15] F. Han, R. Mücke, T. Van Gestel, A. Leonide, N. H. Menzler, H. P. Buchkremer, D. Stöver, Journal of Power Sources 218 (2012) 157-162.

[16] L.R. Pederson, P. Singh, X.-D. Zhou, Vacuum 80 (2006) 1066-1083.

[17] I. Kosacki, C. M. Rouleau, P. F. Becher, J. Bentley, D. H. Lowndes, Solid State Ionics 176 (2005) 1319-1326.

[18] J. H. Shim, C.-C. Chao, H. Huang, F. B. Prinz, Chemistry of Materials 19 (2007) 3850-3854. 
[19] A. Karthikeyan, C.-L. Chang, S. Ramanathan, Applied Physics Letters 89 (2006) 183116.

[20] F. Smeacetto, M. Salvo, L. C. Ajitdoss, S. Perero, T. Moskalewicz, S. Boldrini, L. Doubova, M. Ferraris Materials Letters 64 (2010) 2450-2453.

[21] M. Sillassen, P. Eklund, M. Sridharan, N. Pryds, N. Bonanos, J. Bøttiger, Journal of Applied Physics 105 (2009) 104907.

[22] C. Brahim, A. Ringuedé, E. Gourba ,M. Cassir, A. Billard, P. Briois, Journal of Power Sources 156 (2006) 45-49.

[23] F. C. Fonseca, S. Uhlenbruck, R. Nédélec, D. Sebold, H. P. Buchkremer, Journal of The Electrochemical Society, 157 (2010) B1515-B1519.

[24] EG\&G Technical Services Inc., Fuel Cell Handbook, $7^{\text {th }}$ ed., National Energy Technology Laboratory, Morgan Town, USA (2004).

[25] S. C. Singhal, K. Kendall (Eds.), High Temperature Solid Oxide Fuel Cells: Fundamentals, Design and Applications, Elsevier Advanced Technology, Oxford, UK (2003).

[26] J.-J. Choi, D-S. Park, B.-G. Seong, H.-Y. Bae, International Journal of Hydrogen Energy 37 (2012) 9809-9815.

[27] L. Blum, W. A. Meulenberg, H. Nabielek, and R. Steinberger-Wilckens, International Journal of Applied Ceramic Technology 2 (2005) 482-492.

[28] J. H. J. S. Thijssen, The Impact of Scale-Up and Production Volume on SOFC Manufacturing Cost, National Energy Technology Laboratory, Morgan Town, USA (2007).

[29] C. Xia in: J. W. Fergus, J. Zhang, X. Li, D. P. Wilkinson, and R. Hui (Eds.) Solid Oxide Fuel Cells: Materials Properties and Performance, CRC press, Boca Raton, USA (2009), chapter 1.

[30] A.B. Stambouli, E. Traversa, Renewable and Sustainable Energy Reviews 6 (2002) $433-455$.

[31] S. P. S Badwal, Solid State lonics 52 (1992) 23-32.

[32] http://www.doitpoms.ac.uk/tlplib/fuel-cells/sofc_electrolyte.php last accessed November 2013

[33] H. Inaba, H. Tagawa, Solid State Ionics 83 (1996) 1-16. 
[34] D. A. Andersson, S. I. Simak, N. V. Skorodumova, I. A. Abrikosov, B. Johansson, Proceedings of the National Academy of Sciences of the United States of America 103 (2006) 3518-3521.

[35] B. H. C Steele, Solid State Ionics 129 (2000) 95-110.

[36] T.S. Zhang, J. Ma, H. Cheng, S. H. Chan, Materials Research Bulletin 41 (2006) $563-568$.

[37] S. Zha, C. Xia, G. Meng, Journal of Power Sources 115 (2003) 44-48.

[38] T.S. Zhang, J. Ma, L.B. Kong, S.H. Chan, J.A. Kilner, Solid State Ionics 170 (2004) 209-217.

[39] C. Sun, R. Hui, J. Roller, Journal of Solid State Electrochemistry 14 (2010) 11251144.

[40] J. Mizusaki, Y. Yonemura, H. Kamata, K. Ohyama, N. Mori , H. Takai, H. Tagawa, M. Dokiya, K. Naraya, T. Sasamoto, H. Inaba, T. Hashimoto, Solid State Ionics 132 (2000) 167-180.

[41] E. Ivers-Tiffée, A. Weber, D. Herbstritt, Journal of the European Ceramic Society 21 (2001) 1805-1811.

[42] O. Yamamoto, Y. Takeda, R. Kanno, M. Noda, Solid State Ionics, 22 (1987) 241246.

[43] H. Ullmann, N. Trofimenko, F. Tietz, D. Stöver, A. Ahmad-Khanlou Solid State Ionics 138 (2000) 79-90.

[44] G.Ch. Kostogloudis, G. Tsiniarakis, Ch. Ftikos, Solid State Ionics 135 (2000) 529535 .

[45] P. Plonczak, M. Joost, J. Hjelm, M. Søgaard, M. Lundberg, P.V. Hendriksen, Journal of Power Sources 196 (2011) 1156-1162.

[46] S. Uhlenbruck, N. Jordan, D. Sebold, H. P. Buchkremer, V.A.C Haanappel, D. Stöver, Thin Solid Films 515 (2007) 4053-4060.

[47] R. Knibbe, J. Hjelm, M. Menon, N. Pryds, M. Søgaard, H. J. Wang, K. Neufeld, Journal of the American Ceramic Society 93 (2010) 2877-2883.

[48] W. Z. Zhu, S. C. Deevi, Materials Science and Engineering A 362 (2003) 228-239.

[49] J. Malzbender, E. Wessel, R. W. Steinbrech, Solid State Ionics 176 (2005) 22012203.

[50] X.-M. Ge, S.-H. Chan, Q.-L. Liu, Q. Sun, Advanced Energy Materials 2 (2012) 1156-1181. 
[51] A. Atkinson, S. Barnett, R. J. Gorte, J. T. S. Irvine, A. J. McEvoy, M. Mogensen, S. C. Singhal, J.Vohs, Nature Materials 3 (2004) 17-27.

[52] J. Wu and X. Liu, Journal of Materials Science and Technology 26 (2010) 293-305.

[53] M. C. Tucker, H. Kurokawa, C. P. Jacobson, L. C. De Jonghe, S. J. Visco, Journal of Power Sources 160 (2006) 130-138.

[54] M. K. Mahapatra, K. Lu, Materials Science and Engineering R 67 (2010) 65-85.

[55] M. C. Tucker, Journal of Power Sources 195 (2010) 4570-4582.

[56] P. Blennow, J. Hjelm, T. Klemensø, S. Ramousse, A. Kromp, A. Leonide, A. Weber, Journal of Power Sources 196 (2011) 7117-7125.

[57] M. Paunovic, M. Schlesinger (Eds.) Modern Electroplating, $5^{\text {th }}$ ed., Wiley, Hoboken, USA (2010).

[58] M. Ohring, The Materials Science of Thin Films, $2^{\text {nd }}$ ed., Academic Press Inc., San Diego, USA (2002).

[59] D. M. Mattox, Handbook of Physical Vapor Deposition (PVD) Processing, $2^{\text {nd }}$ ed., William Andrew, Oxford, UK (2010).

[60] X.-T. Yan, Y. Xu, Chemical Vapour Deposition - An Integrated Engineering Design for Advanced Materials, Springer, London, UK (2010).

[61] J. L. Vossen, W. Kern, Thin Film Processes II, Academic Press Inc., San Diego, USA (1991).

[62] J. R. Roth, Industrial Plasma Engineering Volume 1: Principles, Institute of Physics, Bristol, UK (1995).

[63] P. Sigmund, Physical Review 184 (1969) 383-416.

[64] Homepage of the National Physics Laboratory:

http://resource.npl.co.uk/docs/science_technology/nanotechnology/sputter_yield_values/ arsputtertable.pdf last accessed October 2013.

[65] I. Petrov, P. B. Barna, L. Hultman, J. E. Greene, Journal of Vacuum Science and Technology A 21 (2003) 117-128.

[66] I. Safi, Surface and Coatings Technology 127 (2000) 203-219.

[67] W. D. Sproul, D. J. Christie, D. C. Carter, Thin Solid Films 491 (2005) 1-17.

[68] P.J. Kelly, R.D. Arnell, Vacuum 56 (2000) 159-172. 
[69] U. Helmersson, M. Lattemann, J. Bohlmark, A. P. Ehiasarian, J. T. Gudmundsson, Thin Solid Films 513 (2006) 1-24.

[70] V. Kouznetsov, K. Macák, J. M. Schneider, U. Helmersson, I. Petrov, Surface and Coatings Technology 122 (1999) 290-293.

[71] K. Sarakinos, J. Alami, S. Konstantinidis, Surface and Coatings Technology 204 (2010) 1661-1684.

[72] J. Bohlmark, J. Alami, C. Christou, A.P. Ehiasarian, U. Helmersson, Journal of Vacuum Science and Technology A: Vacuum, Surfaces, and Films 23 (2005) 18-22.

[73] J. Alami, K. Sarakinos, F. Uslu, M. Wuttig, Journal of Physics D: Applied Physics 42 (2009) 015304.

[74] G. Greczynski, J. Jensen, J. Böhlmark, L. Hultman, Surface and Coatings Technology 205 (2010) 118-130.

[75] A.P. Ehiasarian, P.E. Hovsepian, L. Hultman, U. Helmersson, Thin Solid Films 457 (2004) 270-277.

[76] J. T. Gudmundsson, N. Brenning, D. Lundin, U. Helmersson, Journal of Vacuum Science \& Technology A 30 (2012) 030801.

[77] D. Mattox in: R. F. Bunshah (Ed.), Handbook of Deposition Technologies for Films and Coatings, 2nd ed., Noyes Publications, New Jersey, USA (1994), chapter 6.

[78] www.CemeCon.de last accessed November 2013

[79] D. A. Porter and K. E. Easterling, Phase transformations in metals and alloys, Taylor \& Francis, Boca Raton, FL, USA (1992)

[80] T. Hata, K. Sasaki, Y. Ichikawa, K. Sasaki, Vacuum 59 (2000) 381-389.

[81] J. Jiang, W. Shen, J. L. Hertz, Thin Solid Films 522 (2012) 66-70.

[82] M. Sillassen, P. Eklund, N. Pryds, E. Johnson, U. Helmersson, J. Bøttiger, Advanced Functional Materials, 20 (2010) 2071-2076.

[83] P. B. Barna, M. Adamik, Thin Solid Films 317 (1998) 27-33.

[84] J. A. Thornton, Annual Reviews in Materials Science 7 (1977) 239-260.

[85] A. Anders, Thin Solid Films 518 (2010) 4087-4090.

[86] D. Brandon and W. D. Kaplan, Microstructural Characterization of Materials, $2^{\text {nd }}$ ed., John Wiley \& Sons Ltd, Chichester, England (2008). 
[87] M. Birkholz, Thin Film Analysis by X-ray Scattering, Wiley-VHC Verlag GmbH \& Co. KGaA, Weinheim, Germany (2006).

[88] H. Klug, L. E. Alexander, X-ray diffraction procedures, 2nd ed., John Wiley \& Sons Inc., New York, USA (1974).

[89] Th. H. de Keijser, J. I. Langford, E. J. Mittemeijer, A. B. P. Vogels, Journal of Applied Crystallography 15 (1982) 308-314.

[90] P. J. Goodhew, F. J. Humphreys, R. Beanland, Electron microscopy and analysis, $3^{\text {rd }}$ ed., Taylor \& Francis, London, UK (2001).

[91] D. Stokes, Principles and practice of variable pressure/environmental scanning electron microscopy (VP-ESEM), Chichester, U.K., Wiley (2008).

[92] D. Brandon and W. D. Kaplan, Microstructural Characterization of Materials, $2^{\text {nd }}$ ed., John Wiley \& Sons Ltd, West Sussex, England (2008).

[93] D. B. Williams and C. B. Carter, Transmission Electron Microscopy: A Textbook for Materials Science, Plenum Press, New York, USA (1996).

[94] J. Goldstein, D. Newbury, D. Joy, C. Lyman, P. Echlin, E. Lifshin, L. Sawyer, and J. Michael, Scanning Electron Microscopy and X-ray Microanalysis, $3^{\text {rd }}$ ed., Springer, New York, USA (2003).

[95] O. Benka, in: G. Friedbacher, H. Bubert (Eds.), Surface and Thin Film Analysis; A Compendium of Principles, Instrumentation, and Applications, $2^{\text {nd }}$ ed., Wiley-VCH Verlag GmbH \& Co. KGaA, Weinheim, Germany (2011), chapter 13.

[96] L. Palmetshofer in: G. Friedbacher, H. Bubert (Eds.), Surface and Thin Film Analysis; A Compendium of Principles, Instrumentation, and Applications, $2^{\text {nd }}$ ed., Wiley-VCH Verlag GmbH \& Co. KGaA, Weinheim, Germany (2011), chapter 11.

[97] W. K. Chu, J. W. Mayer, M.-A. Nicolett, T. M. Buck, G. Amsel, F. Eisen, Thin Solid Films, 17 (1973) 1-41.

[98] M. Mayer, SIMNRA User's Guide, Report IPP 9/113, Max-Planck-Institut für Plasmaphysik, Germany (1997).

[99] M. Mogensen, P. V. Hendriksen in: S. C. Singhal, K. Kendall (Eds.), High Temperature Solid Oxide Fuel Cells: Fundamentals, Design and Applications, Elsevier Advanced Technology, Oxford, UK (2003), chapter 10.

[100] E. Barsoukov, J. R. Macdonald (Eds.), Impedance Spectroscopy: Theory, Experiment, and Applications, $2^{\text {nd }}$ ed., John Wiley \& Sons, Inc., Hoboken, USA (2005).

[101] S. H. Jensen, A. Hauch, P. V. Hendriksen, M. Mogensen, N. Bonanos, T. Jacobsen, Journal of The Electrochemical Society 154 (2007) B1325-B1330. 
[102] P. Briois, A. Billard, Surface \& Coatings Technology 201 (2006) 1328-1334.

[103] P. Coddet, M.C. Pera, A. Billard, Surface \& Coatings Technology 205 (2011) 3987-3991.

[104] S. Rey-Mermet, Y. Yan, C. Sandu, G. Deng, P. Muralt, Thin Solid Films 518 (2010) 4743-4746.

[105] R. Nédélec, S. Uhlenbruck, D. Sebold, V.A.C. Haanappel, H.-P. Buchkremer, D. Stöver, Journal of Power Sources 205 (2012) 157-163.

[106] R. Barfod, A. Hagen, S. Ramousse, P. V. Hendriksen, M. Mogensen, Fuel Cells 6 (2006) 141-145.

[107] J. L. M. Rupp, Solid State Ionics 207 (2012) 1-13.

[108] http://www.teknologisk.dk/_root/media/51581_CGO\%20datablad.pdf last accessed November 2013 


\section{Included Papers}

The articles associated with this thesis have been removed for copyright reasons. For more details about these see:

http://urn.kb.se/resolve?urn=urn:nbn:se:liu:diva-102513 